\title{
Engineered Nuclear Hormone Receptor-Biosensors for Environmental Monitoring and Early Drug Discovery
}

\author{
David W. Wood and Izabela Gierach \\ The Ohio State University
}

USA

\section{Introduction}

Bacterial Biosensors are engineered microorganisms that can be used to detect a variety of chemicals. These chemicals can include heavy metals, toxins, hormones, hormone-like drugs and environmental endocrine-disrupting pollutants. In general, bacterial biosensors are engineered to express a biosensing protein, which can selectively bind to a target chemical (usually referred to as a "ligand"). When the target ligand is present, the biosensor protein produces an easily readable change in the cell behaviour. For example, the biosensing protein may produce a change in fluorescence or enzyme activity, or as shown in Fig. $1 \& 2$, may change the growth rate of the expressing cell when an appropriate ligand is present (Gillies et al, 2008; Skretas et al, 2007; Skretas \& Wood, 2005a, 2005b, 2005c).

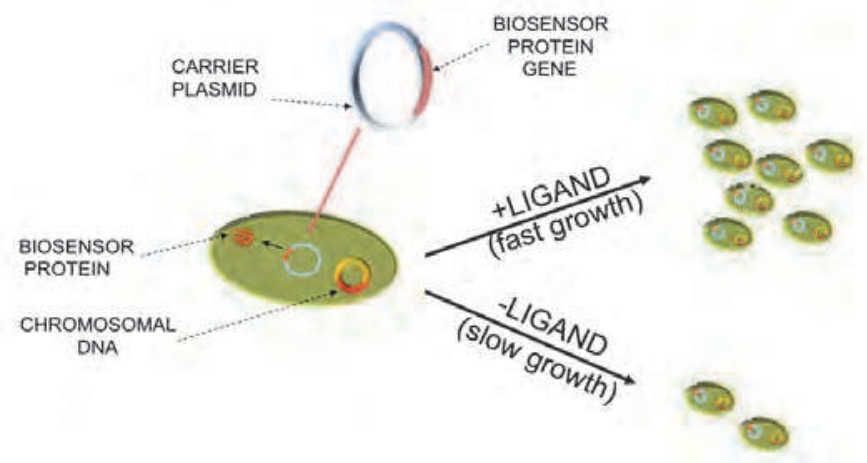

Fig. 1. Growth dependent bacterial biosensor cell. A reporter protein gene is contained on a carrier plasmid, which is transformed into a microbial strain. The expressed biosensor protein produces a ligand-sensitive growth phenotype. In this case, the presence of the appropriate ligand for the biosensor protein increases the growth rate of the biosensor cells.

The bacterial biosensors described in this chapter have been developed specifically for detecting and identifying chemicals that target human and animal nuclear hormone receptors (NHRs). As such, they can be used for identifying potentially valuable drugs for 
treating a variety of cancers and metabolic disorders, or they can be used to detect and identify pathogenic environmental chemicals that act through various NHRs. In drug discovery, the link between chemicals binding to NHRs and various disease states is recognized across many different metazoans (Hu et al, 2008; Jofre \& Karasov, 2008).

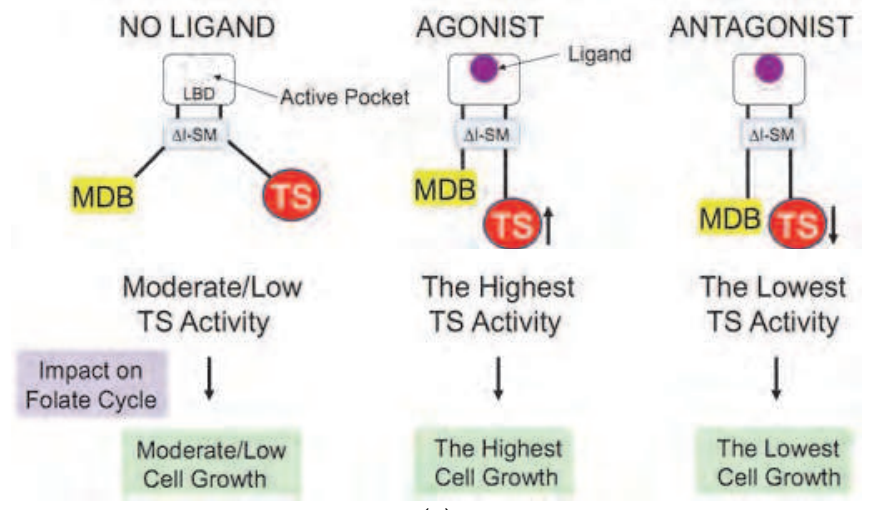

(a)

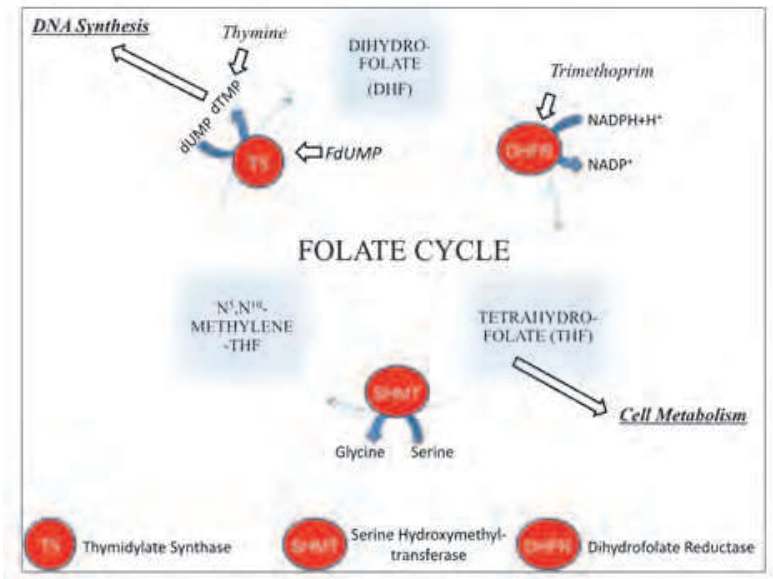

(b)

Fig. 2. (a) Schematic representation of the NHR biosensor protein and related growth phenotypes (Gillies et al, 2008; Skretas et al, 2007; Skretas \& Wood, 2005a). The activity of the TS reporter enzyme is dependent on the configuration of the allosteric sensor protein, which is modulated by the binding of an NHR ligand. The activity of TS affects bacterial DNA synthesis and cellular metabolism (b). The resulting change in growth phenotype can be quantified by optical absorbance at $600 \mathrm{~nm}$ in liquid growth medium, allowing an indirect determination of the ligand's agonistic or antagonistic behaviour. Abbreviations: $\Delta \mathrm{I}-$ SM (mini-intein splicing domain); MDB-maltose binding domain; TS-thymidylate synthase; dUMP- deoxyuridine monophosphate; dTMP- deoxythymidine monophosphate; FdUMP5-fluoro-2'-deoxyuridine 5'-monophosphate; NADP- nicotinamide adenine dinucleotide phosphate; LBD-ligand binding domain of nuclear hormone receptor. 
In humans, aberrant NHR binding of native and other hormone-like compounds is associated with a wide variety of disorders (Grycewicz \& Cypryk, 2008), including dyslipidemia, hypogonadism, endometriosis, cancer, obesity and diabetes, as well as reproductive organ dysfunction and infertility (Feldman et al, 2008; Fessler, 2008; Malm et al, 2007; Mattsson \& Olsson, 2007; Ohno, 2008; Tancevski et al, 2009; Tokumoto et al, 2007). Mitigation of these and other disorders, however, can also be accomplished through NHR manipulation, where hormone-like compounds can reverse or otherwise treat a wide variety of diseases. Similar pathogenic NHR binding effects can be seen in animals, where hormonal imbalances arise from environmental endocrine disrupting compounds (EDCs), such as pollutants and insecticides. These imbalances can lead to infertile egg production, tissue abnormalities, degraded gonadal structure, demasculization, altered species metamorphosis patterns and abnormally fast growth (Fernandez et al, 2007; Hu et al, 2008; Katsu et al, 2007; Rempel \& Schlenk, 2008). For this reason, identification of EDCs and environmental screening for endocrine disrupting activity is a critical application as well.

In humans, there are six major NHR groups, the best studied of which include the Estrogen Receptor (ER-like), Thyroid Hormone Receptor (TR-like) and Retinoid X Receptor (RXRlike) (Doweyko, 2007). Inside the cells, these NHRs bind to DNA and various transcriptional co-activators and co-repressors to regulate the transcription of large numbers of genes in response to their hormone ligands. This ability gives NHRs a tremendous impact on cell maturation, metabolism and homeostasis (Acosta-Martinez et al, 2007; Baxter \& Webb, 2009; Brettes \& Mathelin, 2008).

A key element of the NHRs is that, in addition to their native hormones, they can bind to a wide variety of endocrine disruptors (EDs) and complex pharmaceuticals (Fig. 3). Further, several subtypes can exist for a given NHR family (e.g., ER $\alpha$ or $\operatorname{ER} \beta$, and TR $\alpha$ or TR $\beta$ ). Environmental pollutant EDs that target NHRs include BPA, PCBs, and dioxins, while endocrine active compounds in foods can include vitamins, phospholipids, phytoestrogens and fatty acids. Many pharmaceuticals have been developed to target NHRs, with the most important compounds typically exhibiting highly subtype-selective binding within an NHR group. Notable examples include the Selective Estrogen Receptor Modulators (SERMs; e.g. Raloxifene and Tamoxifen), and the Selective Thyroid Hormone Receptor Modulator (STRM; e.g. Eprotirome, currently in Phase II clinical trials) (Baxter et al, 2004; Leung et al, 2007). The NHR proteins can also form homo- or hetero- dimers and tetramers within the NHR subclasses (e.g., ER-ER; ER-RXR), and can form various combinations of subtype homo- and heterodimers (e.g., ER $\alpha$-ER $\beta$ dimer). These aspects of NHR action can greatly complicate their function in various cells and organs, leading to a wide variety of tissuespecific effects in response to ligands of various classes.

The similar structures and functions of the NHRs makes them a perfect fit for engineering biosensors, especially since they can be expressed well in bacteria or yeast cells. Additionally, the mechanism by which ligand binding triggers gene expression is well known, which has made NHRs and NHR LBDs highly tractable for drug discovery and environmental screening in high throughput systems. There are two basic classifications for compounds that bind to NHRs: agonists and antagonists. In general, agonist compounds tend to trigger hormone-related gene transcription, while antagonists tend to suppress transcription. The exact response of a cell to a given endocrine active compound, however, depends on a variety of factors, which include the presence of various co-activators and corepressors and aspects of the metabolic state of the cell. At the molecular level, the primary determinant for the differential response of the NHR to these two types of compounds is the 


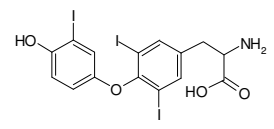

$\mathrm{T}_{3}$<smiles>Cc1cc(OCC(=O)O)cc(C)c1Oc1ccc(O)c(C(C)C)c1</smiles>

GC-1<smiles>O=C(c1ccc(O)cc1O)c1ccc(O)cc1O</smiles>

BENZOPHENONE-2<smiles>CC1(O)CCC2C3CCc4cc(O)ccc4C3CCC21</smiles>

$\mathrm{E}_{2}$

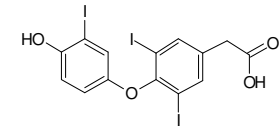

TRIAC<smiles>CC(C)CC(C)(c1ccccc1)c1ccc(OC(C)C)cc1</smiles>

TAMOXIFEN

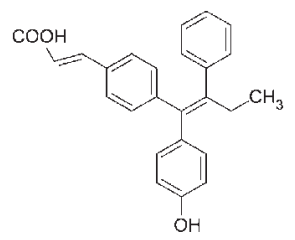

GW7604<smiles>Cc1ccc(CCCCCCOc2ccccc2)cc1</smiles>

BPA

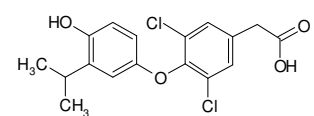

KB-141

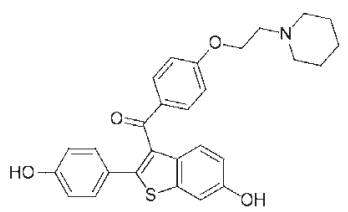

RALOXIFENE<smiles>Cc1ccc(O)cc1C1Oc2ccc(O)cc2C1c1ccc(OCc2ccccc2)cc1</smiles>

EM652

DES

Fig. 3. Selected structures of compounds binding to NHRs. Thyroid receptor ligands include the compounds $\mathrm{T}_{3}$ (a natural TR agonist), TRIAC (a natural TR agonist), KB-141 (a synthetic TR $\beta$-selective agonist) and GC-1 (a synthetic TR $\beta$-selective agonist), while estrogen receptors bind tamoxifen (a subtype-selective ER modulator), raloxifene (a subtype-selective ER modulator), benzophenone-2 (an ER agonist found in many cosmetics and perfumes), GW7604 (a synthetic selective ER downregulator), EM652 (a synthetic selective ER downregulator), $\mathrm{E}_{2}$ (17- $\beta$-estradiol - the native ER ligand), BPA (an ER agonist and suspected ER-disruptor found in many consumer plastics), and DES (an ER agonist, formerly available small-molecule therapeutic which has been linked to cervical cancer).

repositioning of a conserved helix, generally known as helix-12 (Fig. 4a), upon ligand binding (Gulla \& Budil, 2007; Shiau et al, 2002). When the bound ligand is an agonist, helix12 tends to shift towards the NHR binding pocket, creating a charged area on the protein surface. This surface is then occupied by a co-activator, which results in initiation of transcription (MacGregor \& Jordan, 1998; Schapira et al, 2000; Shiau et al, 1998). Antagonists are commonly equipped with bulky functional side group(s), causing helix-12 to rotate 
away from the binding pocket, which typically results in suppression of transcription (Fig. 4a; (Koehler et al, 2005)).
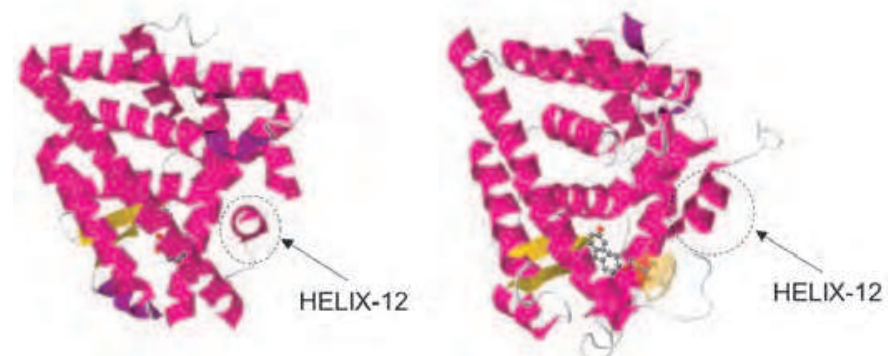

AGONIST GENISTEIN
ANTAGONIST 4-HYDROXYTAMOXIFEN

(a)

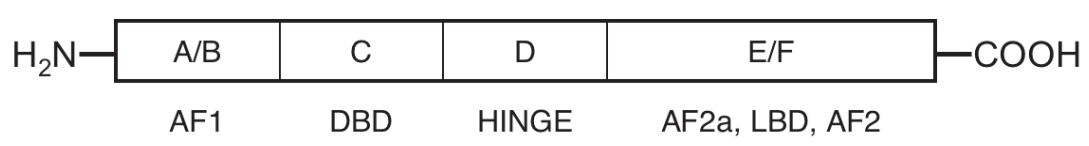

(b)

Fig. 4. (a) Comparison of ER ligand binding domain structures, with a focus on helix-12 repositioning in response to agonist binding (left; ER $\alpha$ bound to genistein, PDB ID: 1X7R) or antagonist (right; ER $\beta$ bound to 4-hydroxytamoxifen, or Nolvadex ${ }^{\circledR}$, a common drug used in treatment for breast cancer patients, PDB ID: 3ERT). The solvent accessible surface around 4hydroxytamoxifen (structure shown in Fig. 3) is underlined in yellow on the right side of the compound. Genistein is inside of the active pocket, hidden behind the $\alpha$-helixes. Upon antagonist binding to ER, helix-12 rotates away from the binding pocket due to the antagonist's extended functional group. This results in a change of the protein surface, making it inaccessible to co-activators. (b) Schematic representation of the NHR domains A through F (Hewitt \& Korach, 2002; Norris et al, 1997). Abbreviations: AF-1 = Activation Function-1; AF-2a = Activation Function-2a; AF2 = Activation Function-2; DBD = DNA Binding Domain.

\section{Engineered allosteric bacterial biosensor}

In any screening process, the success of finding unique and active compounds depends greatly on the sensitivity of the method. A large diversity of available target proteins for screening is also essential, especially when searching for subtype-selective agonistic and antagonistic behaviours. Additionally, assay limitations must also be considered, such as the impacts of solvents used for delivering the test compounds, as well as growth media or temperature. These aspects of the assay can greatly affect the numbers of false positive and false negative results, as well as the reproducibility and robustness of the assay. Finally, for high throughput applications in large library drug screening, the assay must be simple, economical, and amenable to full or partial automation. 
To generate bacterial biosensors for detecting hormones and hormone-like compounds, we have engineered the ligand-binding domains of various NHR proteins into an allosteric biosensor protein scaffold. The biosensor scaffold is composed of four protein domains, including a maltose binding domain, an intein stabilization domain, an NHR ligand-binding domain (LBD), and a thymidylate synthase (TS) reporter enzyme (Fig. 2). This scaffold is designed to link ligand binding by the NHR LBD to the activity of the fused TS reporter protein. Thymidylate synthase is a critical enzyme involved in bacterial DNA synthesis, which produces a strong growth phenotype on thymineless medium based on its activity. Specifically, the TS protein is part of bacterial folate metabolism, where it consumes a single methylene tetrahydrofolate molecule as it converts a single molecule of dUMP to dTMP. The dTMP is then used for DNA synthesis, which is required for cell growth. In practice, the chimeric sensor protein undergoes a structural change when an appropriate ligand is bound to the LBD, which alters the activity of the fused TS domain, and leads to a change in growth rate of the expressing bacterial cell (Fig. 2). The involvement of TS in the folate cycle allows both positive and negative selections for TS activity. Further, the stringency of the selection can be tuned by modulating the incubation temperature and concentrations of the antibiotic trimethoprim (Belfort \& Pedersen-Lane, 1984; Gillies et al, 2008; Skretas et al, 2007; Skretas \& Wood, 2005a). Although there are some differences between species, NHRs share similar domain structures and sequences within the subgroups, which have allowed new NHR biosensors to be generated using the same basic sensor protein scaffold. The biosensing microbial strains expressing these proteins are referred to as "Bacterial Biosensors".

The NHR bacterial biosensors can be used to screen uncharacterized compounds for their effects on a variety of NHR targets. In particular, this method can be used for the detection and differentiation of agonistic and antagonistic compounds, and can be used to determine the half-maximal effective concentrations $\left(\mathrm{EC}_{50}\right.$ and $\mathrm{IC}_{50}$ values) for a given compound (Skretas et al, 2007; Skretas \& Wood, 2005a). Additionally, these bacterial biosensors can detect NHR subtype selectivity of a given compound, as well as species selectivity when used with animal-based bacterial biosensors (Gierach et al, 2011). In this case, the simple incorporation of an animal NHR ligand-binding domain generates a sensor for detecting ligands against that species.

The recognition of agonistic or antagonistic behaviour is directly correlated with TS activity of the sensor, expressed as an increase or decrease of cell growth on selective growth medium (Skretas \& Wood, 2005a). In this selection system, TS activity closely depends on the conformation of the LBD-ligand complex. Reduced activity of the TS reporter enzyme, which is observed in the absence of ligands, or with non-binding or antagonistic ligands, results in lower bacterial growth. High TS activity is elicited by agonist binding and can be detected by observing the rate of increase in culture optical density at $600 \mathrm{~nm}\left(\mathrm{OD}_{600}\right)$ over time. Importantly, the temperature plays an important role in the sensitivity of biosensors, and is related to the stability of TS and the cellular demand for dTMP. Therefore, bacterial cell growth is typically carried out in 96-well plates, incubated at precisely $34^{\circ} \mathrm{C}$ in a controlled humidity air shaker at $150 \mathrm{rpm}$ (Gawrys et al, 2009; Gierach et al, 2011).

\section{Key features of the bacterial biosensors}

1. Each biosensor protein contains: Maltose Binding Protein-Intein-T4 Thymidylate Synthase Enzyme, with the NHR LBD inserted into the intein domain.

2. The activity of the fused TS enzyme is modulated by the amount and potency of the NHR ligand present. 
3. TS activity can be detected qualitatively by colony formation on selective agar medium, or both qualitatively and quantitatively by observing changes in liquid growth medium optical density at $600 \mathrm{~nm}$ wavelength over time.

4. The LBD domain of one biosensor protein can be easily replaced with an alternate LBD, which has allowed the construction of functional biosensors for human ER $\alpha, E R \beta, T R \alpha$, TR $\beta$, PPAR $\gamma$, fish (sole) ER $\beta$ and porcine (domestic pig) ER $\beta$.

5. The assay method is non-radioactive, and has been developed for high throughput screening (HTS).

6. This method can detect strong ligands at low $\mathrm{nM}$ concentrations.

7. Weakly bound ligands, such as BPA and Tamoxifen for the human estrogen receptor, can be detected at low $\mu \mathrm{M}$ concentrations.

8. Three steps are required to complete a single set of assays: (a) overnight growth of fresh cells in non-selective LB medium; (b) dilution of the cells into a selective thymineless medium (-THY medium) and addition of the diluted test compounds and controls (this is done robotically in the HTS format); and (c) growth of cultures for 10 to 20 hours at $34^{\circ} \mathrm{C}, 150 \mathrm{rpm}$ agitation and controlled humidity.

9. The limitations of the method are: the biosensor is sensitive to the presence of detergents, high levels of alcohols, solvents, and lipids (or any generally cytotoxic condition). Therefore, the final solvent concentration used in the assay should not exceed $1 \%$ DMSO or ethanol (test compound vehicle).

\subsection{Construction of the bacterial biosensor strain}

\section{Vector and chimeric proteins}

The biosensor protein is expressed from the pMal-c2 plasmid (New England Biolabs, Beverly, MA), where the plasmid backbone encodes the maltose binding protein (MBD) under control of the Ptac promoter. The biosensor gene is constructed through the following steps (Fig. 5): (1) the $\Delta \mathrm{I}-\mathrm{SM}$ gene, derived from the full-length Mycobacterium tuberculosis RecA intein (Wood et al, 1999), is fused to the C-terminus of the MBD; (2) the bacteriophage T4 $t d$ gene, encoding T4 TS reporter enzyme, is fused to the C-terminus of the $\triangle \mathrm{I}-\mathrm{SM}$ gene; (3) the native intein splicing activity is suppressed by mutation of the $\mathrm{N}$ - and Cterminal amino acids of the intein to alanine; (4) the NHR LBD is inserted into the $\Delta \mathrm{I}$ miniintein gene at the location where the original intein endonuclease domain was deleted; and (5) the Ptac promoter sequence is mutated to slightly increase basal expression of the overall fusion protein (Skretas \& Wood, 2005b). The resulting plasmid names have the general form pMIT::[NHR], where pMIT stands for plasmid MBD- $\Delta$ I intein-TS reporter scaffold, and [NHR] is the inserted LBD (Fig. 5). The constructed sensor plasmids are then transformed into the E. coli TS knockout strain D1210 4 thyA::KanR [F- $\Delta$ (gpt-proA)62 leuB6 supE44 ara-14 galK2 lacY1 $\Delta$ (mcrC-mrr) rpsL20 (Strr) xyl-5 mtl-1 recA13 lacIq] (Skretas et al, 2007).

A key component of the biosensor protein is the split $\Delta \mathrm{I}-\mathrm{SM}$ mini-intein domain, which is thought to increase the stability of the overall fusion and transduce binding information to the TS enzyme. Mutations at the N-terminus of the mini-intein (Cys $\rightarrow$ Ala) suppresses intein splicing, while the MBD was added to assure the solubility and increase the activity of the chimeric protein. Insertion of the NHR LBD is commonly accomplished by utilizing unique AgeI and XhoI restriction sites within the intein, which flank the intein-NHR insertion site (Skretas \& Wood, 2005b). The constructed biosensors include two different mini-inteins for 
LBD insertion: $110 \Delta 383$ and $96 \Delta 400$ (Wood et al, 1999). The $110 \Delta 383$ mini-intein was used more often, and includes the pMIT::ER $\beta^{*}(h), p M I T:: \operatorname{ER} \beta^{*}(s), p M I T:: E R \beta^{*}(p), \operatorname{pMIT::TR} \beta^{*}(h)$ and pMIT::TR $\alpha^{*}(\mathrm{~h})$ biosensors, whereas the $96 \Delta 400$ intein was used for the pMIT::ER $\alpha^{*}(\mathrm{~h})$ fusion (Gierach et al, 2011). The specific mechanism of the biosensor action in bacterial cells is currently under investigation.

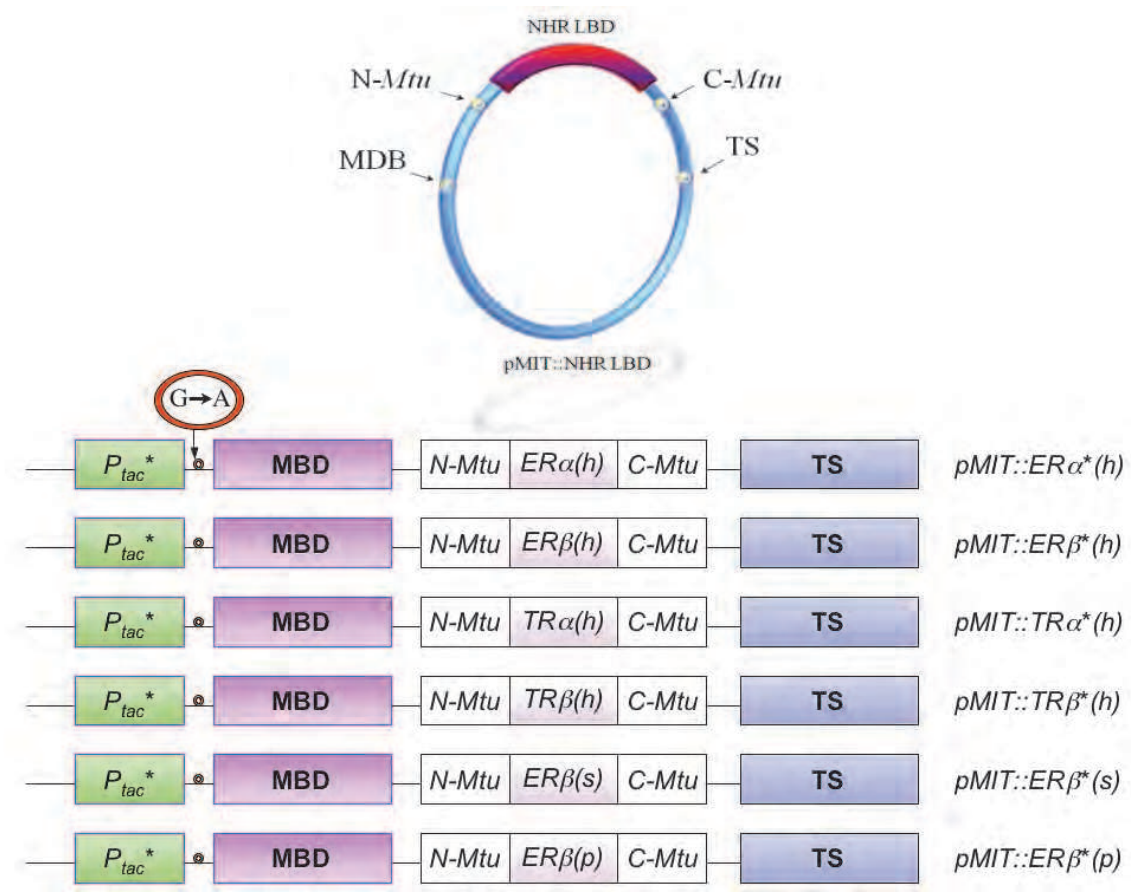

Fig. 5. Schematic representation of the plasmid vector pMal-c2 (top), which contains the MBD, intein, NHR LBD and TS genes. The swappable NHR LBD gene is inserted between the $\mathrm{N}$ - and C-terminal fragments of the intein. Several constructed biosensor protein fusion genes are also shown (bottom). In these diagrams, $\mathrm{P}_{\text {tac }}=\mathrm{Ptac}$ promoter for controlling biosensor protein expression; $\mathrm{MBD}=$ Maltose Binding Domain; N-Mtu $=\mathrm{N}$-terminal segment (typically amino acids 1-110) of the $\Delta \mathrm{I}$-SM mini-intein; ER $\alpha, E R \beta, T R \alpha, T R \beta=$ Estrogen Receptors alpha and beta, Thyroid Receptors alpha and beta, respectively, where $(\mathrm{h})=$ human,$(\mathrm{p})=$ porcine and $(\mathrm{s})=$ sole; $\mathrm{C}-\mathrm{Mtu}=\mathrm{C}$-terminal segment of the $\Delta \mathrm{I}-\mathrm{SM}$ miniintein; TS = Thymidylate Synthase reporter enzyme. Plasmid names are shown on the right for each of the biosensor genes, where pMIT stands for plasmid MBD- $\Delta \mathrm{I}-\mathrm{TS}$ and the :: symbol indicates insertion of the indicated LBD.

\subsection{Usage of the NHR bacterial biosensors}

\subsubsection{The High Throughput Screening (HTS)}

The application of bacterial biosensors in a 96-well plate HTS format (Fig. 6) is based on an earlier protocol that employed glass culture tubes. The original glass culture tube method was very labor-intensive, and the number of samples and concentrations was limited by incubator space. Most importantly, large quantities of growth medium and ligands were 
needed for each experiment. The HTS method in 96-well plates is approximately 100 times more sensitive, and the cells, growth medium and ligands are dispensed by a robotic liquid handler (Biomek 2000, Beckman-Coulter), which assures greater mixing quality and repeatability.

\subsubsection{Agonism and antagonism detection by biosensors}

There are three major tests resulting in detection of ligand agonism and antagonism, as well as toxicity of the test compounds for bacterial cells (see Table 1).

Compounds that stimulate the growth of cells in thymineless medium (-THY) are generally considered to be agonists, while antagonists can have no effect, or in some cases can decrease the growth of cells in -THY medium. Using estrogen receptor as an example, antagonist tests use competitive biosensor binding with estradiol (-THY $+\mathrm{E}_{2}$ assay), where antagonist lowers TS activity relative to $\mathrm{E}_{2}$ alone. However, in the TTM and TTM+E $\mathrm{E}_{2}$ assays the phenotypes are reversed, and low TS activity upon antagonist binding rescues cells. This reversal is very helpful in confirming LBD-specific effects, as opposed to more general metabolic effects. Toxicity can be determined by adding an uncharacterized compound to cells growing in non-selective medium (+THY), where cells grow freely in the presence of agonists or antagonists, but toxicity results in a loss of growth.

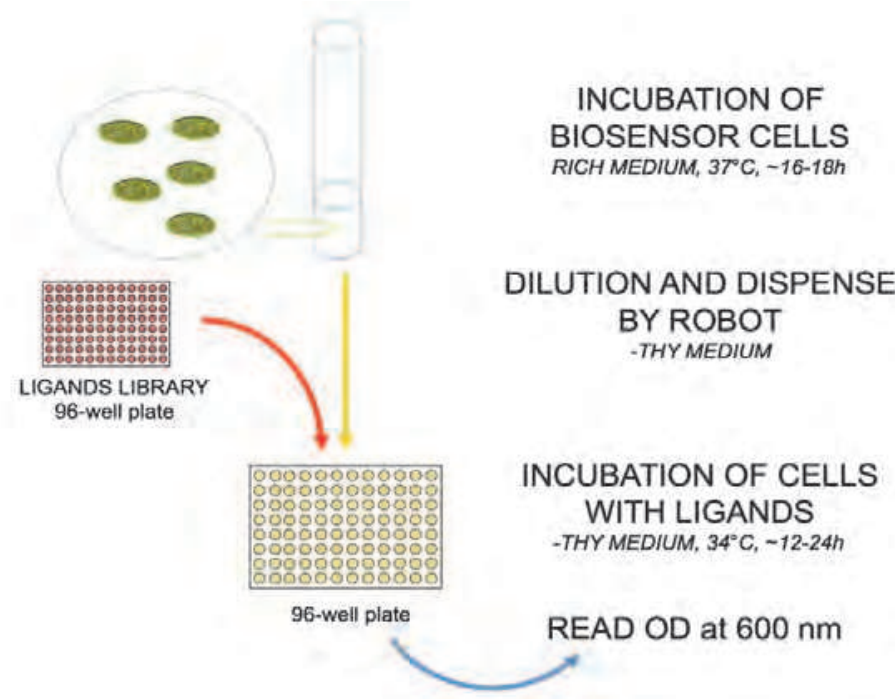

Fig. 6. Schematic representation of the intein-based biosensor method.

\subsubsection{Sub-type receptor selectivity}

The ligand binding domains of receptor subtypes are highly conserved (see Fig. 4), which allows multiple receptor subtypes to be used for biosensor generation. Differential binding to one biosensor subtype or another allows a quick determination of subtype selectivity for a given compound. In previous studies, we were able to confirm the subtype-selectivity of compounds bound to the estrogen receptors. Among them propylpyrazole triol (PPT) and methyl piperidinopyrazole (MPP) were found ER $\alpha$ selective, whereas DPN, Genistein and 
Daidzein were ER $\beta$ selective. The Relative Binding Affinities (the $\mathrm{EC}_{50}$ ratio between $\mathrm{ER} \alpha$ and ER $\beta$ ) of those compounds were in correlation with the literature; PPT (593), MPP (220), DPN (0.01), Genistein (0.002) and Daidzein (0.2) (Skretas \& Wood, 2005b). Additionally, the TR biosensors were able to detect Triac, GC-1 and KB-141 TR $\beta$ selectivity (unpublished results), which are also in agreement with reported results (Bleicher et al, 2008; Grover et al, 2005; Koury et al, 2009; Li et al, 2006; Marimuthu et al, 2002; Martinez et al, 2009; Scanlan, 2008; Wagner et al, 2001).

\begin{tabular}{cc|ccccc} 
& & $\begin{array}{c}-\mathbf{T H Y} \\
34^{\circ} \mathrm{C}\end{array}$ & $\begin{array}{c}-\mathbf{T H Y}+\mathrm{E}_{2} \\
34^{\circ} \mathrm{C}\end{array}$ & $\begin{array}{c}\text { TTM } \\
37^{\circ} \mathrm{C}\end{array}$ & $\begin{array}{c}\text { TTM+E } \\
37^{\circ} \mathrm{C}\end{array}$ & $\begin{array}{c}+\mathbf{T H Y} \\
37^{\circ} \mathrm{C}\end{array}$ \\
\hline $\begin{array}{c}\text { High TS } \\
\text { Activity }\end{array}$ & AGONISM & + & + & - & - & + \\
$\begin{array}{c}\text { Low TS } \\
\text { Activity }\end{array}$ & ANTAGONISM & - & - & + & + & + \\
$\begin{array}{l}\text { Low TS } \\
\text { Activity }\end{array}$ & TOXICITY & $\mathrm{n} / \mathrm{a}$ & $\mathrm{n} / \mathrm{a}$ & $\mathrm{n} / \mathrm{a}$ & $\mathrm{n} / \mathrm{a}$ & -
\end{tabular}

Table 1. Summary of the NHR bacterial biosensor assays and their conditions, including temperatures and growth medium additives for optimizing results (Skretas et al, 2007). The $+/$ - signs indicate cell growth below or above the baseline $\mathrm{OD}_{600}$ value obtained for cells in the presence of solvent only (which is constant throughout the sample and not higher than

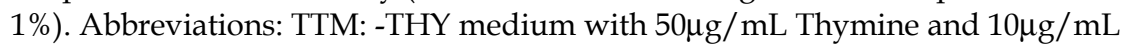
Trimethoprim; +THY: -THY medium with $50 \mu \mathrm{g} / \mathrm{mL}$ Thymine; $\mathrm{E}_{2}$ is $17-\beta$-estradiol, typically at 0.1 to $10 \mu \mathrm{M}$ depending on the test strain.

\subsubsection{Effect of compounds across different species}

We also confirmed in our studies that the effects of tested compounds varied across different species, such as sole (Solea solea) and human (Gierach et al, 2011). As expected, compounds expressed similar effects when bound to pig and human ER $\beta$ s, but in some cases diverged for sole and human or pig. The fact that the biosensors are able to quantify differential effects across species can allow rapid screening of ED pollutants using consistent assay protocols, which will eliminate important barriers to comparing these types of data in the current literature. This creates great opportunities for understanding crosstalk of receptors in a wide range of species, and allows the selectivity of ligands across receptors and species to be explored.

\subsubsection{Synergism and competition of natural hormones, pharmaceuticals and EDCs}

There is a great concern that mixtures of EDCs could have stronger and more devastating effects than single compounds on health and environment. Since there is no limitation as to how many ligands can be tested simultaneously, the biosensor could detect synergistic effects acting through the NHR LBD as well.

\section{Bacterial biosensors in drug discovery}

The process of delivering new pharmaceuticals to the market takes approximately 10-15 years and only one compound in 10,000 has a chance to be approved by the U.S. FDA. The 
development cost per drug can reach $\$ 800$ million on average (Brower, 2002). For these reasons, there is an urgency to discover new compounds that are more selective and have fewer side effects. Early stage discovery and pre-clinical research may take 6-7 years alone.
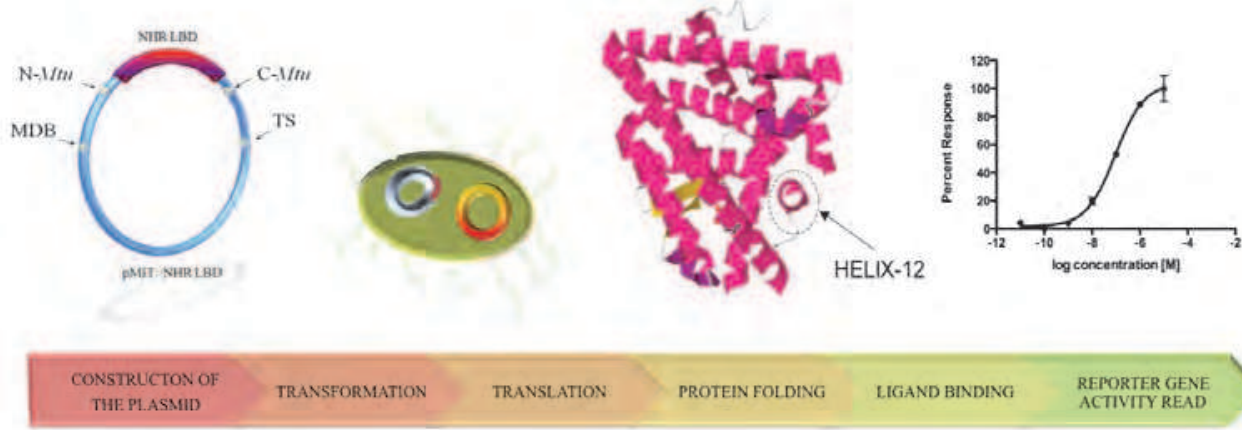

Fig. 7. The process of designing a bacterial biosensor and its utilization. First, the sequence of the plasmid is constructed computationally. The template (e.g., pMIT::ER $\alpha$ ) stays intact, and the insert (N-terminal intein-NHR LBD-C-terminal intein) is swapped to create a new biosensor with a different LBD. Next, the plasmid is transformed into a bacterial cell, which allows the encoded gene to be transcribed and translated into the active biosensor protein. In the presence of an agonist, the activity level of the TS reporter enzyme domain is increased, leading to an increase in cellular growth rate (see the graph above). However, when antagonists are present the activity of the TS is low, which allows a distinction between these two types of the compounds. Cell growth can be quantified by $\mathrm{OD}_{600}$ measurements. The 3D structures of NHR LBDs proteins (such as the ER LBD shown above) can be found in the RCSB Protein Data Bank (PDB).

Therefore, the development of new methods to rapidly screen millions of ligands against new targets is essential and ongoing. The identification of ligands that bind to estrogen receptor(s) began with the development of treatments for patients with hormonal dysfunctions, cancers, and sexually transmitted bacterial infections. Several early pharmaceuticals, such as diethylstilbestrol (DES, a nonsteroidal estrogen synthesized just before World War II by Leon Golberg), failed due to their high toxicity and disastrous side effects, such as breast cancer and vaginal adenocarcinoma in second-generation girls (Birch, 1992; Jordan et al, 2008). The first human ER was discovered in 1966 by Jensen and Gorski, and it took an additional 30 years until the first mammalian ER $\beta$ sequence was cloned (Fannon et al, 2001). Interestingly, the compound tamoxifen, as well as second-generation benzothiophene derivative selective estrogen receptor modulators (SERMs) (e.g., raloxifene, known as Evista ${ }^{\circledR}$ (Pritchard, 2001; Wilkinson et al, 1982)), show unique selective action in targeted tissues. In some tissues SERMs act as an estrogen, and therefore their action is described as agonistic, but in others they block the effect of estrogen and behave as antagonists. In many cases, the mechanism of SERM action is not fully understood, and research is ongoing on the roles of the co-regulators, ligands, and cross-signaling proteins that mediate ER expression levels across the human body. For example, it was determined that ER $\beta$ is dominant in the gastrointestinal tract, whereas ER $\alpha$ dominates in liver. Both of these receptors are expressed in breast, bone and brain tissue, but in different ratios, 
allowing direct targeting of specific organs (Gustafsson, 1999). During the last 10 years, the number of targeted drug-like compounds produced in industry and academia has increased dramatically. These compounds have been developed as fertility drugs, as well as breast cancer, prostate cancer and osteoporosis therapeutics. Among them are Toremifene (Fareston ${ }^{\circledR}$ by Shire laboratories), lasofoxifene, trioxifene, droloxifene, clomifene (Clomid ${ }^{\circledR}$ by Hoechst Marion Roussel, Inc.) and ormeloxifene (originally manufactured by Torrent Pharmaceuticals), which was used as a birth control pill, and is now also prescribed to cure uterine bleeding (Blizzard, 2008; Fan et al, 2007; Musa et al, 2007; Sanceau et al, 2007). Pure antagonists were also synthesized such as ICI 182,780 (Faslodex ${ }^{\circledR}$ by AstraZeneca), which is known as a selective estrogen receptor downregulator; SERD (Abdou et al, 2008).

In previous research, we showed that bacterial biosensors could detect novel compounds and determine their behavior as agonists or antagonists (see structures of discovered compounds in Fig. 8 and Table 2) (Hartman et al, 2009; Skretas et al, 2007). Compounds a and $\mathbf{b}$ were found to bind to ER, and their agonistic and antagonistic effects were verified using biosensors. The new findings were confirmed by a fluorescence polarization displacement assay using extracts of human ER $\beta$ and ER $\alpha$ and fluorescently labeled estrogen, as well as by analyzing ERE-dependent luciferase gene activity in human embryonic kidney HEK:ER $\beta$ and breast cancer MCF-7:D5L cells. The relative binding affinities of these compounds, determined by competitive binding assays, showed the ER $\beta$ selectivity of compound $\mathbf{b}$. Specifically, the RBA (relative binding affinities of the compound to estrogen) of compound $\mathbf{a}$ and $\mathbf{b}$ for ER $\alpha$ were $0.23 \pm 0.03$ and $0.59 \pm 0.09$, and for ER $\beta$ were $1.94 \pm 0.024$ and $0.78 \pm 0.10$, respectively (Skretas et al, 2007). An additional study using a luciferase reporter system revealed that compound $\mathbf{a}$ is an agonist, but compound $\mathbf{b}$ is a partial agonist and partial agonist/antagonist when bound to ER $\alpha$ and ER $\beta$, respectively.

\begin{tabular}{|c|c|c|c|c|c|}
\hline \multirow{2}{*}{ Compound } & \multicolumn{2}{|c|}{ Bacterial Biosensor } & \multirow{2}{*}{ Compound } & \multicolumn{2}{c|}{ Bacterial Biosensor } \\
\cline { 2 - 3 } \cline { 5 - 6 } & Agonist & Antagonists & & Agonist & Antagonists \\
\hline DES & + & - & Tamoxifen & - & + \\
\hline $\begin{array}{c}17-\beta- \\
\text { estradiol }\end{array}$ & + & - & 4-hydroxytamoxifen & - & + \\
\hline Estriol & + & - & Clomiphene & - & + \\
\hline $\begin{array}{c}17-\alpha- \\
\text { estradiol }\end{array}$ & + & - & Raloxifene & - & + \\
\hline Estrone & + & - & ICI182,780 & - & + \\
\hline
\end{tabular}

Table 2. Bacterial biosensor results obtained for hormones and pharmaceuticals screened against human ER $\beta$ (Skretas et al, 2007). Concentration of the ligands was $5 \mu \mathrm{M}$, with the exception of tamoxifen at $2 \mu \mathrm{M}$. Antagonists were tested in competitive assays against 500 $\mathrm{nM} \mathrm{E}_{2}$. The (+/-) symbols indicate a positive/negative cell growth outcome.

The other two compounds, $\mathbf{c}$ and $\mathbf{d}$, were originally discovered using a computational method known as Shape Signatures (Hartman et al, 2009; Nagarajan et al, 2005; Zauhar et al, 2003). Shape Signatures was created to rapidly compare chemical databases against known active compounds to detect similar bioactivity. This in silico method screens specifically for polarity and shape similarities by initially using a ray-tracing algorithm well known in the 
movie industry to computationally draw shapes of objects in 3D space. The solventaccessible surface of each molecule is defined by a Smooth Molecular Surface Triangulator algorithm (Zauhar, 1995), and is essential for defining the volume of a molecule. The shape of the molecule, as well as the molecular electrostatic potential computed over the surface of the molecule, can be compared across large databases and scored rapidly for the most promising compounds. The two molecules $\mathbf{c}$ and $\mathbf{d}$ (Fig. 8) were derived from a Shape Signatures screening against GW7604 and EM652 (see Fig. 3).

Compounds $\mathbf{c}$ and $\mathbf{d}$ were determined to bind to the active pocket of ER using ComputerAided Drug Design methods, and their behavior was examined using the bacterial biosensors and an ER $\alpha$ activation immunoassay (ELISA) containing MCF-7 cell extract (Hartman et al, 2009; Skretas et al, 2007). The predicted binding mode of compound c overlapped the position of Tamoxifen, which binds through weaker van der Waals interactions to the active pocket. Compound $\mathbf{d}$ showed possible hydrogen bond formation with Glu353. Overall, compounds $\mathbf{c}$ and $\mathbf{d}$ were found to be orally bioavailable by Lipinski's Rule of Five, which takes into account solubility, molecular weight, and even the number of rotational bonds and hydrogen bond donors and acceptors (Hartman et al, 2009).

(a)

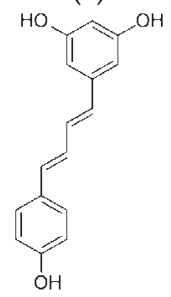

AGONIST

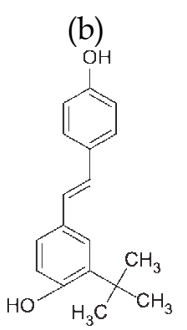

PARTIAL AGONIST/ANTAGONIST

(c)

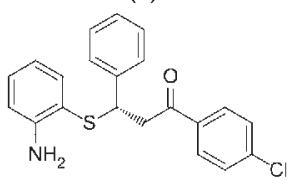

ANTAGONIST (d)

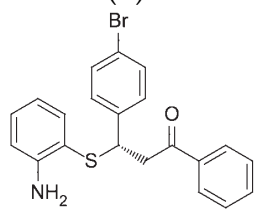

ANTAGONIST

Fig. 8. The structures of agonists and antagonists discovered and confirmed by commercial as well as conventional methods ER (Hartman et al, 2009; Skretas et al, 2007). Names of the compounds: (a) 5-[(1E,3E)-4-(4-hydroxyphenyl)-1,3-butadien-1-yl]-1,3-benzenediol; (b) 2 (1,1-dimethylethyl)-4-[(1E)-2-(4-hydroxyphenyl)ethenyl]-phenol; (c) 3-(2 aminophenyl)sulfanyl-1-(4-chlorophenyl)-3-phenyl-propan-1-one; (d) 3-(2 aminophenyl)sulfanyl-3-(4-bromophenyl)-1-phenyl-propan-1-one.

\section{Environmental endocrine disruptors detection}

Synthetic or natural compounds that interfere with hormonal and homeostatic systems are known as Endocrine Disruptors (EDs) (Nilsson, 2000). The targets of EDs can be NHRs, nonhormonal receptors, or numerous biological pathways involved in hormone synthesis, metabolism and excretion. Thus, EDs can cause serious disruption of the endocrine system by mimicking natural hormones, which may lead to increased or inhibited transcription of hormone-regulated genes. Some of these compounds are now associated with various cancers, genetic and reproductive diseases, as well as behavioral and developmental abnormalities. A few ED-associated disorders seen in humans are also manifest in other species, and include uterine leiomyomas, endometriosis, cancers, diabetes and obesity (Bryzgalova et al, 2008; Cook et al, 2007; Goksoyr, 2006; Koda et al, 2007; Kuiper et al, 2007; 
Lee et al, 2007; Lingxia et al, 2007; Maffini et al, 2006; Negri-Cesi et al, 2008; Nilsson, 2000; Safe, 2000). EDs comprise a wide range of chemicals, including solvents, pesticides, and pharmaceuticals (e.g., DES), and even naturally occurring phytoestrogens in plants (McKinlay et al, 2008). Some EDs accumulate in the body, such as uranium from nuclear power plants, lead, mercury and cadmium, which travel to the brain and kidney (RaymondWhish et al, 2007; Strumylaite et al, 2008; Vahter et al, 2007). Some weakly binding compounds, such as BPA, are embedded in plastic bottles used for water and soft drinks (Vandenberg et al, 2007). In particular, BPA has been shown to bind to hormone receptors across different species. Despite numerous studies on the negative effects of BPA (Vandenberg et al, 2009), to this day its impact on the body is still controversial. However, the EPA and FDA are now moving to update their disclosures on BPA in response to an internal BPA study showing negative effects of exposure on the brain and prostate, as well as on the behavior of infants and children (Keri et al, 2007).

\begin{tabular}{|c|c|}
\hline Compound & Source \\
\hline Hexestrol & Synthetic, DES derivative \\
\hline Genistein & Isoflavone, found in plants e.g. soybeans \\
\hline Kaempferol & Flavonoid, found in plants e.g. tea, apples \\
\hline Naringenin & Flavonoid, found in plants e.g. grapefruit \\
\hline Diphenylnitrosamine (DPN) & Synthetic \\
\hline BPA & Plastics; e.g. bottles, caps \\
\hline Apigenin & Flavonoid, found in plants e.g. parsley, celery \\
\hline Zearalanols & Found in plants e.g. fungi (Fusarium) \\
\hline Biochanin A & Flavonoid, found in plants e.g. peanuts, soy \\
\hline Daidzein & Isoflavone, naturally found in plants e.g. soybeans \\
\hline Phloretin & Found in plants e.g. apple leaves \\
\hline Naringenin & Flavonoid, found in plants e.g. grapefruit \\
\hline
\end{tabular}

Table 3. Selected ER agonists detected by bacterial biosensors, including phytogestrogens and synthetic estrogen analogs. BPA, DPN and 17- $\beta$-estradiol (natural hormone, ER agonist) were additionally confirmed to be agonists in the sole and pig ER $\beta$ biosensors. BPA and Daidzein, despite the fact that they are weak ER agonists, were also detected (Breinholt \& Larsen, 1998; Collins et al, 1997; Kuiper et al, 1997; Kuiper et al, 1998; Skretas et al, 2007).

One of the difficulties in determining the impact of EDs on the human body is that although a broad range of assays are available, their results are generally not directly comparable. For example, the detection limit of a given compound can vary by a factor of 1000 or more across several different in-vivo and in-vitro assays (Charles, 2004; Dobbins et al, 2008; Kramer, 1998). Measuring the impacts of these compounds on humans is also very difficult, especially when evaluating the cumulative impact of EDs over time on the body. Often, these assays cannot distinguish between high overall toxicity of EDs and their agonistic and antagonistic effects. Non-sigmoidal functions are also observed for some EDs, which exhibit U-shaped and inverted-U-shaped dual dose response curves, such as those seen for phytoestrogens and neurotransmitters. For example, at low concentrations some compounds may act as agonists, but at high concentrations they may behave more like 
antagonists (Li et al, 2007; Pinto et al, 2008). Additionally, EDs typically exist in the environment in mixtures, and therefore there is a need for newly developed HTS assays to assess their effects alone and in combination with other compounds (Charles et al, 2007). The effect of an ED alone or in a mixture of EDs in different assays may also vary (Benachour et al, 2007; Ramamoorthy et al, 1997).

Since EDs can be accumulated in the body, their half-life could be longer than expected, and contact with these chemicals more frequent than expected. For example, the BPA daily safe uptake is $50 \mu \mathrm{g} / \mathrm{kg}$ as determined by the EPA, but it accumulates in fat tissue over time. Therefore, additive daily exposure occurs, resulting from a longer than expected half-life in the human body (Diamanti-Kandarakis, 2009). Therefore, understanding the impact of these chemicals on the endocrine system and human health is challenging, especially for weakly binding EDs like BPA.

The bacterial biosensors can easily differentiate between bacterial toxicity and endocrine activity. Examples of compounds that bind to ERs, and their sources, are shown in Table 3 Some of them are naturally occurring chemicals found in plants, but others are synthetic. In each case, these compounds mimic estrogen, but their structure is not typically steroid-like (see examples of DES, BPA in Fig. 3). In some cases, the compounds could be beneficial (e.g., chemopreventive properties of Apigenin; antidepressant properties of Kaempferol) as well as harmful or epigenetic (BPA, DES and Hexestrol).

\subsection{Screening of home products for estrogenic activity}

The intein-based biosensors are capable of detecting small amounts of estrogenic compounds in consumer products such as perfumes, pills and plant extracts. A study using the bacterial biosensors showed that chemicals such as benzophenone-2 (see Fig. 3), which is a UV absorber used in plastic food containers and cosmetics, can be detected by this method. Benzophenone-2 (BP-2) has an agonistic effect on the human ER, and several publications suggest estrogenic effects on fish (juvenile fathead minnows) as well rats (Kunz et al, 2006; Schlecht et al, 2008; Seidlova-Wuttke et al, 2004). In other studies, BP-2 was shown to have an agonistic effect on fish (rainbow trout) and human ERs, and was found to be selective for human ER $\beta$ in an in vitro bioassay (Molina-Molina et al, 2008). BP-2 was also tested in pregnant mice to determine its impact on fetuses, where it was found that BP-2 may be a cause of hypospadia which is an abnormality in the reproductive organs of male fetuses (Hsieh et al, 2007). Additionally, BP-2 suppresses T4 (thyroid hormone), but not T3, and has estrogenic activity in rats (Seidlova-Wuttke et al, 2005). The results obtained by the bacterial biosensors also suggest an agonistic effect of BP-2 on the human ER $\beta$. Several perfumes were tested, including Notes by Celine Dion, Amber Romance by Victoria's Secret, Roma by Laura Biagiotti and Haiku by Avon. All of the tested perfumes that contain BP-2 as an ingredient had an agonistic effect on ER $\beta$ biosensor, but no effect on the TR $\beta$ biosensor. Tests of several natural menopause-relief pills showed a weak positive effect in many cases as well, which included Black Cohosh and Dong Quai Capsules by Nature's Way, and Black Cohosh and Dong Quai Capsules by Gaia Herbs. Notably, essential oils (e.g., Lavender Oil by Plantlife) and soaps were screened but were toxic to the bacterial cells (Gawrys et al, 2009).

\subsection{Testing endocrine disruptors across species}

The human NHR LBDs of the biosensors can be easily exchanged for animal LBDs and the effects due to the same set of ligands can be compared. The sequences of ER $\beta$ for Sus scrofa 
and Solea solea were inserted in place of human ER $\beta$ in the pMIT::ER $\beta^{*}$, and the potencies of DES, BPA, DPN, Daidzein and $E_{2}$ were compared. The potencies across species showed that DES and $E_{2}$ have the strongest effect on all of fish, pig and human biosensors. DES was almost twice as effective on pig than on fish or human. The weakest effect was noticed for $\mathrm{BPA}$ in the order human>fish>pig. The half maximal effective concentrations $\left(\mathrm{EC}_{50} \mathrm{~s}\right)$ were compared to determine relative pseudotransactivation (RPTA, see Equation (1)). The $\mathrm{EC}_{50}$ values and the standard deviations of data obtained in triplicate can be presented as sigmoidal plots of OD vs. log of test compound concentration. The calculations were based on nonlinear regression with variable Hill slope (GraphPad Prism 5.01; GraphPad Software, La Jolla, CA, USA).

$$
\mathrm{RPTA}=\frac{\mathrm{EC}_{50}^{\mathrm{E}_{2}}}{\mathrm{EC}_{50}^{\text {ligand }}} \times 100 \%
$$

However, the RPTA values for DPN were quite close to $\mathrm{E}_{2}$ for human ( $\left.80 \%\right)$, but showed it to be less potent for pig (33\%) and fish $(12 \%)$. An even smaller relative effect was seen for Daidzein, commonly found in soybeans, on human ERß $(4 \%) \approx$ pig $(4 \%)>$ fish $(0.9 \%)$. Similarly, BPA had very little effect on fish $(5.6 \%)>$ human $(0.9 \%)>$ pig $(0.23 \%)$. The twotailed $\mathrm{p}$ values with $95 \%$ confidence interval verified significant correlation between $\mathrm{EC}_{50}$ values of tested compounds on human and porcine ER $\beta$ s. There was no correlation of those ERs with sole ER $\beta$. To further examine the quality of the assay, the $Z^{\prime}$ factor for each measurement was calculated, which is an indication of signal to noise in a measurement (see Equation (2); (Zhang et al, 1999)). In both cases the data were sufficient to distinguish ER agonists across species in HTS set up, where $Z^{\prime}$ factor above zero is needed to robustly determine whether a given ligand is a potential EDC. In general, all of the tests produced very good $Z^{\prime}$ factors, ranging from the strong agonist $E_{2}$ ( $Z^{\prime}$ factor of $0.4-0.6$ across the three tested species), to the weaker agonist BPA ( $Z^{\prime}$ factor of 0.15-0.32) (Gierach et al, 2011).

$$
Z^{\prime}=1-\frac{3 x\left(\mathrm{SD}_{\text {max }}+\mathrm{SD}_{\min }\right)}{\mid \text { Mean }_{\text {max }}-\text { Mean }_{\text {min }} \mid}
$$

The data obtained here were also compared to the literature. The trends of recorded effects of ligands on human and pig ERs were similar (DES $>>\mathrm{E}_{2}>$ Daidzein $>\mathrm{BPA}$ ). Weaker binders like Daidzein and BPA were also tested previously in a yeast transcriptional assay, and the values obtained from these studies closely correlated with our findings $\left(2.5 \times 10^{-7} \mathrm{M}\right.$ (yeast assay) vs. $1.7 \times 10^{-6} \mathrm{M}$ (bacterial assay) and $1.45 \times 10^{-7} \mathrm{M}$ (yeast assay) vs. $3.6 \times 10^{-7} \mathrm{M}$ (bacterial assay), respectively; (Chu et al, 2009)). The performance of the Solea solea biosensor was more difficult to ascertain, due to a relative lack of available data compared to carp (Cyprinus carpio) and rainbow trout (Oncorhynchus mykiss) (Matthews et al, 2000; Matthews et al, 2001; Petit et al, 1995). In general, however, in vivo tests in other piscine species were less sensitive for weak binders, such as BPA. In this case, a hepatocyte vitellogenin secretion test at up to $100 \mu \mathrm{M}$ concentration of BPA showed limited response (Smeets et al, 1999). Our studies were able to determine the binding effect of BPA in sole at lower concentrations $(0.10$ to $9.85 \mu \mathrm{M})$. In other previous assays where piscine ERs were tested, trends in the strength of binding were similar to those observed for Daidzein and DPN in the bacterial biosensors. The alternate assays included a displacement assay using a trout ER nuclear extract, or the previously mentioned hepatocyte vitellogenin secretion assay. A correlation 
between all of these assays was seen for strong binders, such as $E_{2}$, which closely corresponded with in vivo studies: 50-150 nM (vitellogenin assay) (Smeets et al, 1999) vs. 21$153 \mathrm{nM}$ (bacterial biosensor assay).

\begin{tabular}{|c|c|c|c|}
\hline Method & Detection & Bacterial Host & Reference \\
\hline \multicolumn{4}{|c|}{ Heavy metals } \\
\hline $\begin{array}{l}\text { Green fluorescent } \\
\text { protein (GFP)-based } \\
\text { bacterial biosensors }\end{array}$ & $\begin{array}{l}\mathrm{Cd}(\mathrm{II}), \mathrm{Pb}(\mathrm{II}), \text { and } \mathrm{Sb}(\mathrm{III}) \text { in } \\
\text { sediments and soils }\end{array}$ & Escherichia coli & (Liao et al, 2006) \\
\hline $\begin{array}{l}\text { GFP bacterial } \\
\text { biosensor }\end{array}$ & As & Escherichia coli & (Tani et al, 2009) \\
\hline $\begin{array}{c}\text { Bioluminescent } \\
\text { bacterial biosensor }\end{array}$ & $\mathrm{Cu}, \mathrm{Zn}, \mathrm{Cd}, \mathrm{Co}, \mathrm{Ni}, \mathrm{Pb}$ & $\begin{array}{l}\text { Alcaligenes } \\
\text { eutrophus }\end{array}$ & $\begin{array}{l}\text { (Collard et al, 1994; } \\
\text { Diels et al, 1999) }\end{array}$ \\
\hline $\begin{array}{c}\text { Fibre-optic } \\
\text { luminescent bacterial } \\
\text { biosensors }\end{array}$ & $\mathrm{Hg}$ and As in soils and sediments & Escherichia coli & (Ivask et al, 2007) \\
\hline \multicolumn{4}{|c|}{ Antibiotics } \\
\hline $\begin{array}{c}\text { Colorimetric bacterial } \\
\text { biosensor dipstick- } \\
\text { based technology }\end{array}$ & $\begin{array}{c}\text { Tetracycline, streptogramin and } \\
\text { macrolide in food }\end{array}$ & Escherichia coli & (Link et al, 2007) \\
\hline $\begin{array}{c}\text { Luminescent bacterial } \\
\text { biosensor }\end{array}$ & Tetracyclines in poultry muscle & Escherichia coli & (Pikkemaat et al, 2010) \\
\hline \multicolumn{4}{|c|}{ Hormones, Pharmaceuticals, Endocrine Disruptors } \\
\hline $\begin{array}{c}\text { Cell growth based TS- } \\
\text { deficient NHR } \\
\text { bacterial biosensors }\end{array}$ & \begin{tabular}{|} 
Wide variety of compounds e.g. \\
estradiol, $T_{3}$, triac, tamoxifen, \\
GC-1, diethylstilbestrol, KB-141, \\
daidzein, DPN and genistein
\end{tabular} & Escherichia coli & $\begin{array}{l}\text { (Gawrys et al, 2009; } \\
\text { Hartman et al, 2009; } \\
\text { Skretas et al, 2007; } \\
\text { Skretas \& Wood, 2005a, } \\
\text { 2005b, 2005c ) }\end{array}$ \\
\hline $\begin{array}{c}\text { Electrochemical } \\
\text { bacterial biosensors }\end{array}$ & $\begin{array}{c}\text { Aromatic hydrocarbons and } \\
\text { heavy metals }\end{array}$ & Escherichia coli & (Paitan et al, 2003) \\
\hline $\begin{array}{c}\text { Fluorescent and } \\
\text { luminescent toluene } \\
\text { bacterial biosensors }\end{array}$ & $\begin{array}{c}\text { Environmental pollution with } \\
\text { petroleum products e.g. benzene, } \\
\text { toluene, ethylbenzene, and } \\
\text { xylenes }\end{array}$ & Escherichia coli & (Li et al, 2008) \\
\hline $\begin{array}{c}\text { Bioluminescent } \\
\text { naphthalene biosensor }\end{array}$ & Naphthalene & $\begin{array}{l}\text { Pseudomonas } \\
\text { putida }\end{array}$ & (Werlen et al, 2004) \\
\hline \multicolumn{4}{|c|}{ DNA } \\
\hline $\begin{array}{l}\text { Bioluminescent } \\
\text { bacterial biosensor for } \\
\text { DNA damage, } \\
\text { alkylation and } \\
\text { mutagenicity } \\
\text { recognition }\end{array}$ & \begin{tabular}{|} 
Genotoxicants included: \\
endocrine disrupting chemicals, \\
phenolitics and compounds \\
causing oxidative stress (e.g. \\
$\left.\mathrm{H}_{2} \mathrm{O}_{2}, \mathrm{CdCl}\right)$
\end{tabular} & Escherichia coli & (Ahn et al, 2009) \\
\hline $\begin{array}{l}\text { Microgravity and } \\
\text { space radiation } \\
\text { bacterial biosensors }\end{array}$ & $\begin{array}{c}\text { Analysis of the level of radiation } \\
\text { exposure on human body by } \\
\text { bacterial detection }\end{array}$ & $\begin{array}{l}\text { Salmonella } \\
\text { typhimurium }\end{array}$ & (Rabbow et al, 2003) \\
\hline $\begin{array}{c}\text { Stress-responsive } \\
\text { bacterial biosensors }\end{array}$ & $\begin{array}{c}\text { DNA damage by oxidative and } \\
\text { genotoxic conditions }\end{array}$ & Escherichia coli & (Mitchell \& Gu, 2004) \\
\hline
\end{tabular}

Table 4 . The review of bacterial biosensors usage. 


\section{Brief overview of other bacterial biosensors}

The intein-NHR bacterial biosensors are useful for ED screening and drug discovery, and exhibit many advantages over conventional assays. These advantages are also observed in other bacterial biosensor systems, which have been extended into wide range of applications. These include testing for antibiotics in food, as well as detecting DNA damage by chemicals and even space radiation. Several examples of other bacterial biosensors are included in Table 4.

\section{Conclusions}

The bacterial biosensors presented here are an excellent tool for screening EDs, pharmaceuticals, hormones or mixtures of compounds for their agonism or antagonism against human NHRs as well as NHRs of other species. These biosensors meet the need for a method to rapidly compare the effects of NHR ligands across different species, and to estimate the potential danger of chemicals in the environment. These bacterial biosensors can be also used to rapidly and cheaply test large amounts of the unknown chemicals for possible future uses as lead compounds in pharmaceutical research, including compounds with receptor sub-type selectivity. The simplicity of the assay and very low cost are attractive key features of this method.

\section{Acknowledgment}

This research was supported by National Science Foundation CAREER Award BES-0348220, NIH grant 1R21ES16630 and the Nancy Lurie Marks Family Foundation.

\section{References}

Abdou, N. I., Rider, V., Greenwell, C., Li, X. L.,Kimler, B. F. (2008). Fulvestrant (Faslodex), an estrogen selective receptor downregulator, in therapy of women with systemic lupus erythematosus. Clinical, serologic, bone density, and T cell activation marker studies: A double-blind placebo-controlled trial. Journal of Rheumatology, Vol. 35, No. 5, pp. 797-803, ISSN: 0315-162X.

Acosta-Martinez, M., Horton, T.,Levine, J. E. (2007). Estrogen receptors in neuropeptide Y neurons: at the crossroads of feeding and reproduction. Trends in Endocrinology and Metabolism, Vol. 18, No. 2, pp. 48-50, ISSN: 1043-2760.

Ahn, J. M., Hwang, E. T., Youn, C. H., Banu, D. L., Kim, B. C., Niazi, J. H.,Gu, M. B. (2009). Prediction and classification of the modes of genotoxic actions using bacterial biosensors specific for DNA damages. Biosens Bioelectron, Vol. 25, No. 4, pp. 767772, ISSN: 1873-4235 (Electronic).

Baxter, J. D.,Webb, P. (2009). Thyroid hormone mimetics: potential applications in atherosclerosis, obesity and type 2 diabetes. Nature reviews Drug discovery, Vol. 8, No. 4, pp. 308-320, ISSN: 1474-1784.

Baxter, J. D., Webb, P., Grover, G.,Scanlan, T. S. (2004). Selective activation of thyroid hormone signaling pathways by GC-1: a new approach to controlling cholesterol and body weight. Trends Endocrinol Metab, Vol. 15, No. 4, pp. 154-157, ISSN: 10432760 (Print). 
Belfort, M.,Pedersen-Lane, J. (1984). Genetic system for analyzing Escherichia coli thymidylate synthase. J Bacteriol, Vol. 160, No. 1, pp. 371-378.

Benachour, N., Moslemi, S., Sipahutar, H.,Seralini, G. E. (2007). Cytotoxic effects and aromatase inhibition by xenobiotic endocrine disrupters alone and in combination. Toxicology and Applied Pharmacology, Vol. 222, No. 2, pp. 129-140, ISSN: 0041-008X.

Birch, A. J. (1992). Steroid hormones and the Luftwaffe. A venture into fundamental strategic research and some of its consequences: The Birch reduction becomes a birth reduction. Steroids, Vol. 57, No. 8, pp. 363-377, ISSN: 0039-128X.

Bleicher, L., Aparicio, R., Nunes, F. M., Martinez, L., Gomes Dias, S. M., Figueira, A. C., Santos, M. A., Venturelli, W. H., da Silva, R., Donate, P. M., Neves, F. A., Simeoni, L. A., Baxter, J. D., Webb, P., Skaf, M. S.,Polikarpov, I. (2008). Structural basis of GC-1 selectivity for thyroid hormone receptor isoforms. BMC Struct Biol, Vol. 8, No., pp. 8, ISSN: 1472-6807 (Electronic).

Blizzard, T. A. (2008). Selective Estrogen Receptor Modulator medicinal chemistry at Merck. A review. Current Topics in Medicinal Chemistry, Vol. 8, No. 9, pp. 792-812, ISSN: 1568-0266.

Breinholt, V.,Larsen, J. C. (1998). Detection of weak estrogenic flavonoids using a recombinant yeast strain and a modified MCF7 cell proliferation assay. Chem Res Toxicol, Vol. 11, No. 6, pp. 622-629, ISSN: 0893-228X (Print).

Brettes, J. P.,Mathelin, C. (2008). Dual effects of androgens on mammary gland. Bulletin Du Cancer, Vol. 95, No. 5, pp. 495-502, ISSN: 0007-4551.

Brower, V. (2002). Fast tracking drugs to patients. EMBO Reports, Vol. 3, No. 1, pp. 14-16.

Bryzgalova, G., Effendic, S., Khan, A., Rehnmark, S., Barbounis, P., Boulet, J., Dong, G., Singh, R., Shapses, S., Malm, J., Webb, P., Baxter, J. D.,Grover, G. J. (2008). Antiobesity, anti-diabetic, and lipid lowering effects of the thyroid receptor beta subtype selective agonist KB-141. Journal of Steroid Biochemistry \& Molecular Biology, Vol. 111, No. 3-5, pp. 262-267.

Charles, G. D. (2004). In vitro models in endocrine disruptor screening. Ilar J, Vol. 45, No. 4, pp. 494-501, ISSN: 1084-2020 (Print).

Charles, G. D., Gennings, C., Tornesi, B., Kan, H. L., Zacharewski, T. R., Gollapudi, B. B.,Carney, E. W. (2007). Analysis of the interaction of phytoestrogens and synthetic chemicals: An in vitro/in vivo comparison. Toxicology and Applied Pharmacology, Vol. 218, No. 3, pp. 280-288, ISSN: 0041-008X.

Chu, W. L., Shiizaki, K., Kawanishi, M., Kondo, M.,Yagi, T. (2009). Validation of a new yeast-based reporter assay consisting of human estrogen receptors alpha/beta and coactivator SRC-1: Application for detection of estrogenic activity in environmental samples. Environ Toxicol, Vol.24, No.5, pp.513-521, ISSN: 1522-7278 (Electronic).

Collard, J. M., Corbisier, P., Diels, L., Dong, Q., Jeanthon, C., Mergeay, M., Taghavi, S., van der Lelie, D., Wilmotte, A.,Wuertz, S. (1994). Plasmids for heavy metal resistance in Alcaligenes eutrophus CH34: mechanisms and applications. FEMS Microbiol Rev, Vol. 14, No. 4, pp. 405-414, ISSN: 0168-6445 (Print).

Collins, B. M., McLachlan, J. A.,Arnold, S. F. (1997). The estrogenic and antiestrogenic activities of phytochemicals with the human estrogen receptor expressed in yeast. Steroids, Vol. 62, No. 4, pp. 365-372, ISSN: 0039-128X (Print).

Cook, J. D., Davis, B. J., Goewey, J. A., Berry, T. D.,Walker, C. L. (2007). Identification of a sensitive period for developmental programming that increases risk for uterine leiomyoma in Eker rats. Reproductive Sciences, Vol. 14, No. 2, pp. 121-136, ISSN: 1933-7191. 
Diamanti-Kandarakis, E. B., J.P.; Giudice, L.C.; Hauser, R.; Prins, G.S.; Soto, A.M.; Zoeller, R.T.; Gore, A.C. . (2009). Endocrine-disrupting chemicals: an endocrine society scientific statement. Endocrine Reviews, Vol. 30, No. 4, pp. 293-342, ISSN: 0021-972X (Print).

Diels, L., De Smet, M., Hooyberghs, L.,Corbisier, P. (1999). Heavy metals bioremediation of soil. Mol Biotechnol, Vol. 12, No. 2, pp. 149-158, ISSN: 1073-6085 (Print).

Dobbins, L. L., Brain, R. A.,Brooks, B. W. (2008). Comparison of the sensitivities of common in vitro and in vivo assays of estrogenic activity: application of chemical toxicity distributions. Environ Toxicol Chem, Vol. 27, No. 12, pp. 2608-2616, ISSN: 0730-7268 (Print).

Doweyko, A. M. (2007). Steroid nuclear hormone receptors: The allosteric conversation. Drug Development Research, Vol. 68, No. 3, pp. 95-106, ISSN: 0272-4391.

Fan, M. Y., Rickert, E. L., Chen, L., Aftab, S. A., Nephew, K. P.,Weatherman, R. V. (2007). Characterization of molecular and structural determinants of selective estrogen receptor downregulators. Breast Cancer Research and Treatment, Vol. 103, No. 1, pp. 37-44, ISSN: 0167-6806.

Fannon, S. A., Vidaver, R. M.,Marts, S. A. (2001). An abridged history of sex steroid hormone receptor action. J Appl Physiol, Vol. 91, No. 4, pp. 1854-1859, ISSN: 87507587 (Print).

Feldman, P. L., Lambert, M. H.,Henke, B. R. (2008). PPAR modulators and PPAR pan agonists for metabolic diseases: The next generation of drugs targeting Peroxisome Proliferator-Activated Receptors? Current Topics in Medicinal Chemistry, Vol. 8, No. 9, pp. 728-749, ISSN: 1568-0266.

Fernandez, M. P., Campbell, P. M., Ikonomou, M. G.,Devlin, R. H. (2007). Assessment of environmental estrogens and the intersex/sex reversal capacity for chinook salmon (Oncorhynchus tshawytscha) in primary and final municipal wastewater effluents. Environment International, Vol. 33, No. 3, pp. 391-396, ISSN: 0160-4120.

Fessler, M. B. (2008). Liver X receptor: Crosstalk node for the signaling of lipid metabolism, carbohydrate metabolism, and innate immunity. Current Signal Transduction Therapy, Vol. 3, No. 2, pp. 75-81, ISSN: 1574-3624.

Gawrys, M. D., Hartman, I., Landweber, L. F.,Wood, D. W. (2009). Use of engineered Escherichia coli cells to detect estrogenicity in everyday consumer products. Journal of Chemical Technology \& Biotechnology, Vol. 84, No. 12, pp. 1834-1840, ISSN: 10974660 .

Gierach, I., Shapero, K., Eyster, T. W.,Wood, D. W. (2011). Bacterial biosensors for evaluating potential impacts of estrogenic endocrine disrupting compounds in multiple species. Environmental Toxicology and Chemistry, (in press).

Gillies, A. R., Skretas, G.,Wood, D. W. (2008). Engineered systems for detection and discovery of nuclear hormone-like compounds. Biotechnol Prog, Vol. 24, No. 1, pp. 8-16, ISSN: 8756-7938 (Print).

Goksoyr, A. (2006). Endocrine disruptors in the marine environment: mechanisms of toxicity and their influence on reproductive processes in fish. J Toxicol Environ Health A, Vol. 69, No. 1-2, pp. 175-184, ISSN: 1528-7394 (Print).

Grover, G. J., Mellstrom, K.,Malm, J. (2005). Development of the thyroid hormone receptor beta-subtype agonist KB-141: a strategy for body weight reduction and lipid lowering with minimal cardiac side effects. Cardiovascular Drug Reviews, Vol. 23, No. 2, pp. 133-148. 
Grycewicz, J.,Cypryk, K. (2008). Effect of sex hormones on metabolic disturbances in menopausal women. Przeglad Menopauzalny, Vol. 7, No. 1, pp. 29-37, ISSN: 16438876.

Gulla, S. V.,Budil, D. E. (2007). Ligand induced solution structure and dynamics of the helix12 region of estrogen receptor alpha. Faseb Journal, Vol. 21, No. 5, pp. A253-A253, ISSN: 0892-6638.

Gustafsson, J. A. (1999). Estrogen receptor beta-a new dimension in estrogen mechanism of action. J Endocrinol, Vol. 163, No. 3, pp. 379-383, ISSN: 0022-0795 (Print).

Hartman, I., Gillies, A. R., Arora, S., Andaya, C., Royapet, N., Welsh, W. J., Wood, D. W.,Zauhar, R. J. (2009). Application of screening methods, shape signatures and engineered biosensors in early drug discovery process. Pharm Res, Vol. 26, No. 10, pp. 2247-2258, ISSN: 1573-904X (Electronic).

Hewitt, S. C.,Korach, K. S. (2002). Estrogen receptors: structure, mechanisms and function. Rev Endocr Metab Disord, Vol. 3, No. 3, pp. 193-200, ISSN: 1389-9155 (Print).

Hsieh, M. H., Grantham, E. C., Liu, B., Macapagal, R., Willingham, E.,Baskin, L. S. (2007). In utero exposure to benzophenone-2 causes hypospadias through an estrogen receptor dependent mechanism. J Urol, Vol. 178, No. 4 Pt 2, pp. 1637-1642, ISSN: 0022-5347 (Print).

Hu, F., Smith, E. E.,Carr, J. A. (2008). Effects of larval exposure to estradiol on spermatogenesis and in vitro gonadal steroid secretion in African clawed frogs, Xenopus laevis. General and Comparative Endocrinology, Vol. 155, No. 1, pp. 190-200, ISSN: 0016-6480.

Ivask, A., Green, T., Polyak, B., Mor, A., Kahru, A., Virta, M.,Marks, R. (2007). Fibre-optic bacterial biosensors and their application for the analysis of bioavailable $\mathrm{Hg}$ and As in soils and sediments from Aznalcollar mining area in Spain. Biosens Bioelectron, Vol. 22, No. 7, pp. 1396-1402, ISSN: 0956-5663 (Print).

Jofre, M. B.,Karasov, W. H. (2008). Effect of mono-ortho and di-ortho substituted polychlorinated biphenyl (PCB) congeners on leopard frog survival and sexual development. Chemosphere, Vol. 70, No. 9, pp. 1609-1619, ISSN: 0045-6535.

Jordan, V. C., Patel, R., Lewis-Wambi, J.,Swaby, R. (2008). By looking back we can see the way forward: enhancing the gains achieved with antihormone therapy. Breast Cancer Research, Vol. 10, No. Suppl 4, pp. S16, ISSN: 1465-5411.

Katsu, Y., Lange, A., Urushitani, H., Ichikawa, R., Paull, G. C., Cahill, L. L., Jobling, S., Tyler, C. R.,Iguchi, T. (2007). Functional associations between two estrogen receptors, environmental estrogens, and sexual disruption in the roach (Rutilus rutilus). Environmental Science E Technology, Vol. 41, No. 9, pp. 3368-3374, ISSN: 0013-936X.

Keri, R. A., Ho, S. M., Hunt, P. A., Knudsen, K. E., Soto, A. M.,Prins, G. S. (2007). An evaluation of evidence for the carcinogenic activity of bisphenol A. Reproductive Toxicology, Vol. 24, No. 2, pp. 240-252, ISSN: 0890-6238.

Koda, T., Morita, M.,Imai, H. (2007). Retinoic acid inhibits uterotrophic activity of bisphenol a in adult ovariectomized rats. Journal of Nutritional Science and Vitaminology, Vol. 53, No. 5, pp. 432-436, ISSN: 0301-4800.

Koehler, K. F., Helguero, L. A., Haldosen, L. A., Warner, M.,Gustafsson, J. A. (2005). Reflections on the discovery and significance of estrogen receptor beta. Endocr Rev, Vol. 26, No. 3, pp. 465-478, ISSN: 0163-769X (Print).

Koury, E. J., Pawlyk, A. C., Berrodin, T. J., Smolenski, C. L., Nagpal, S.,Deecher, D. C. (2009). Characterization of ligands for thyroid receptor subtypes and their interactions with co-regulators. Steroids, Vol. 74, No. 2, pp. 270-276, ISSN: 0039-128X (Print). 
Kramer, P. J. (1998). Genetic toxicology. J Pharm Pharmacol, Vol. 50, No. 4, pp. 395-405, ISSN: 0022-3573 (Print).

Kuiper, G. G., Carlsson, B., Grandien, K., Enmark, E., Haggblad, J., Nilsson, S.,Gustafsson, J. A. (1997). Comparison of the ligand binding specificity and transcript tissue distribution of estrogen receptors alpha and beta. Endocrinology, Vol. 138, No. 3, pp. 863-870.

Kuiper, G. G., Lemmen, J. G., Carlsson, B., Corton, J. C., Safe, S. H., van der Saag, P. T., van der Burg, B.,Gustafsson, J. A. (1998). Interaction of estrogenic chemicals and phytoestrogens with estrogen receptor beta. Endocrinology, Vol. 139, No. 10, pp. 4252-4263, ISSN: 0013-7227 (Print).

Kuiper, R. V., Canton, R. F., Leonards, P. E. G., Jenssen, B. M., Dubbeldam, M., Wester, P. W., van den Berg, M., Vos, J. G.,Vethaak, A. D. (2007). Long-term exposure of European flounder (Platichthys flesus) to the flame-retardants tetrabromobisphenol A (TBBPA) and hexabromocyclododecane (HBCD). Ecotoxicology and Environmental Safety, Vol. 67, No. 3, pp. 349-360, ISSN: 0147-6513.

Kunz, P. Y., Galicia, H. F.,Fent, K. (2006). Comparison of in vitro and in vivo estrogenic activity of UV filters in fish. Toxicol Sci, Vol. 90, No. 2, pp. 349-361, ISSN: 1096-6080 (Print).

Lee, Y. M., Seong, M. J., Lee, J. W., Lee, Y. K., Kim, T. M., Nam, S. Y., Kim, D. J., Yun, Y. W., Kim, T. S., Han, S. Y.,Hong, J. T. (2007). Estrogen receptor independent neurotoxic mechanism of bisphenol A, an environmental estrogen. Journal of Veterinary Science, Vol. 8, No. 1, pp. 27-38, ISSN: 1229-845X.

Leung, F. P., Tsang, S. Y., Wong, C. M., Yung, L. M., Chan, Y. C., Leung, H. S., Yao, X. Q.,Huang, Y. (2007). Raloxifene, tamoxifen and vascular tone. Clinical and Experimental Pharmacology and Physiology, Vol. 34, No. 8, pp. 809-813, ISSN: 03051870.

Li, L., Andersen, M. E., Heber, S.,Zhang, Q. (2007). Non-monotonic dose-response relationship in steroid hormone receptor-mediated gene expression. Journal of Molecular Endocrinology, Vol. 38, No. 5-6, pp. 569-585, ISSN: 0952-5041.

Li, Y. F., Li, F. Y., Ho, C. L.,Liao, V. H. (2008). Construction and comparison of fluorescence and bioluminescence bacterial biosensors for the detection of bioavailable toluene and related compounds. Environ Pollut, Vol. 152, No. 1, pp. 123-129, ISSN: 02697491 (Print).

Li, Y. L., Litten, C., Koehler, K. F., Mellstrom, K., Garg, N., Garcia Collazo, A. M., Farnegard, M., Grynfarb, M., Husman, B., Sandberg, J.,Malm, J. (2006). Thyroid receptor ligands. Part 4: 4'-amido bioisosteric ligands selective for the thyroid hormone receptor beta. Bioorg Med Chem Lett, Vol. 16, No. 4, pp. 884-886, ISSN: 0960-894X (Print).

Liao, V. H., Chien, M. T., Tseng, Y. Y.,Ou, K. L. (2006). Assessment of heavy metal bioavailability in contaminated sediments and soils using green fluorescent protein-based bacterial biosensors. Environ Pollut, Vol. 142, No. 1, pp. 17-23, ISSN: 0269-7491 (Print).

Lingxia, X., Taixiang, W.,Xiaoyan, C. (2007). Selective estrogen receptor modulators (SERMs) for uterine leiomyomas. Cochrane Database of Systematic Reviews, ISSN: 1469-493X.

Link, N., Weber, W.,Fussenegger, M. (2007). A novel generic dipstick-based technology for rapid and precise detection of tetracycline, streptogramin and macrolide antibiotics in food samples. J Biotechnol, Vol. 128, No. 3, pp. 668-680, ISSN: 0168-1656 (Print). 
MacGregor, J. I.,Jordan, V. C. (1998). Basic guide to the mechanisms of antiestrogen action. Pharmacol Rev, Vol. 50, No. 2, pp. 151-196, ISSN: 0031-6997 (Print).

Maffini, M. V., Rubin, B. S., Sonnenschein, C.,Soto, A. M. (2006). Endocrine disruptors and reproductive health: the case of bisphenol-A. Mol Cell Endocrinol, Vol. 254-255, No., pp. 179-186, ISSN: 0303-7207 (Print).

Malm, J., Grover, G. J.,Farnegardh, M. (2007). Recent advances in the development of agonists selective for beta1-type thyroid hormone receptor. Mini-Reviews in Medicinal Chemistry, Vol. 7, No. 1, pp. 79-86.

Marimuthu, A., Feng, W., Tagami, T., Nguyen, H., Jameson, J. L., Fletterick, R. J., Baxter, J. D.,West, B. L. (2002). TR surfaces and conformations required to bind nuclear receptor corepressor. Mol Endocrinol, Vol. 16, No. 2, pp. 271-286, ISSN: 0888-8809 (Print).

Martinez, L., Nascimento, A. S., Nunes, F. M., Phillips, K., Aparicio, R., Dias, S. M., Figueira, A. C., Lin, J. H., Nguyen, P., Apriletti, J. W., Neves, F. A., Baxter, J. D., Webb, P., Skaf, M. S.,Polikarpov, I. (2009). Gaining ligand selectivity in thyroid hormone receptors via entropy. Proc Natl Acad Sci U S A, Vol., No., pp., ISSN: 1091-6490 (Electronic).

Matthews, J., Celius, T., Halgren, R.,Zacharewski, T. (2000). Differential estrogen receptor binding of estrogenic substances: a species comparison. J Steroid Biochem Mol Biol, Vol. 74, No. 4, pp. 223-234, ISSN: 0960-0760 (Print).

Matthews, J. B., Clemons, J. H.,Zacharewski, T. R. (2001). Reciprocal mutagenesis between human alpha(L349, M528) and rainbow trout (M317, I496) estrogen receptor residues demonstrates their importance in ligand binding and gene expression at different temperatures. Mol Cell Endocrinol, Vol. 183, No. 1-2, pp. 127-139, ISSN: 0303-7207 (Print).

Mattsson, C.,Olsson, T. (2007). Estrogens and glucocorticoid hormones in adipose tissue metabolism. Current Medicinal Chemistry, Vol. 14, No. 27, pp. 2918-2924, ISSN: 09298673.

McKinlay, R., Plant, J. A., Bell, J. N. B.,Voulvoulis, N. (2008). Endocrine disrupting pesticides: implications for risk assessment. Environment International, Vol. 34, No. 2, pp. 168-183, ISSN: 0160-4120.

Mitchell, R. J.,Gu, M. B. (2004). Construction and characterization of novel dual stressresponsive bacterial biosensors. Biosens Bioelectron, Vol. 19, No. 9, pp. 977-985, ISSN: 0956-5663 (Print).

Molina-Molina, J. M., Escande, A., Pillon, A., Gomez, E., Pakdel, F., Cavailles, V., Olea, N., Ait-Aissa, S.,Balaguer, P. (2008). Profiling of benzophenone derivatives using fish and human estrogen receptor-specific in vitro bioassays. Toxicol Appl Pharmacol, Vol. 232, No. 3, pp. 384-395, ISSN: 1096-0333 (Electronic).

Musa, M. A., Khan, M. O. F.,Cooperwood, J. S. (2007). Medicinal chemistry and emerging strategies applied to the development of selective estrogen receptor modulators (SERMs). Current Medicinal Chemistry, Vol. 14, No. 11, pp. 1249-1261, ISSN: 09298673.

Nagarajan, K., Zauhar, R.,Welsh, W. J. (2005). Enrichment of ligands for the serotonin receptor using the Shape Signatures approach. J Chem Inf Model, Vol. 45, No. 1, pp. 49-57, ISSN: 1549-9596 (Print).

Negri-Cesi, P., Colciago, A., Pravettoni, A., Casati, L., Conti, L.,Celotti, F. (2008). Sexual differentiation of the rodent hypothalamus: Hormonal and environmental 
influences. Journal of Steroid Biochemistry and Molecular Biology, Vol. 109, No. 3-5, pp. 294-299, ISSN: 0960-0760.

Nilsson, R. (2000). Endocrine modulators in the food chain and environment. Toxicol Pathol, Vol. 28, No. 3, pp. 420-431, ISSN: 0192-6233 (Print).

Norris, J. D., Fan, D., Kerner, S. A.,McDonnell, D. P. (1997). Identification of a third autonomous activation domain within the human estrogen receptor. Mol Endocrinol, Vol. 11, No. 6, pp. 747-754, ISSN: 0888-8809 (Print).

Ohno, M. (2008). Functional analysis of nuclear receptor FXR controlling metabolism of cholesterol. Yakugaku Zasshi-Journal of the Pharmaceutical Society of Japan, Vol. 128, No. 3, pp. 343-355, ISSN: 0031-6903.

Paitan, Y., Biran, D., Biran, I., Shechter, N., Babai, R., Rishpon, J.,Ron, E. Z. (2003). On-line and in situ biosensors for monitoring environmental pollution. Biotechnol Adv, Vol. 22, No. 1-2, pp. 27-33, ISSN: 0734-9750 (Print).

Petit, F., Valotaire, Y.,Pakdel, F. (1995). Differential functional activities of rainbow trout and human estrogen receptors expressed in the yeast Saccharomyces cerevisiae. Eur J Biochem, Vol. 233, No. 2, pp. 584-592, ISSN: 0014-2956 (Print).

Pikkemaat, M. G., Rapallini, M. L., Karp, M. T.,Elferink, J. W. (2010). Application of a luminescent bacterial biosensor for the detection of tetracyclines in routine analysis of poultry muscle samples. Food Addit Contam Part A Chem Anal Control Expo Risk Assess, Vol. 27, No. 8, pp. 1112-1117, ISSN: 1944-0057 (Electronic).

Pinto, B., Bertoli, A., Noccioli, C., Garritano, S., Reali, D.,Piqelli, L. (2008). Estradiolantagonistic activity of phenolic compounds from leguminous plants. Phytotherapy Research, Vol. 22, No. 3, pp. 362-366, ISSN: 0951-418X.

Pritchard, K. I. (2001). Breast cancer prevention with selective estrogen receptor modulators: a perspective. Ann N Y Acad Sci, Vol. 949, No., pp. 89-98, ISSN: 0077-8923 (Print).

Rabbow, E., Rettberg, P., Baumstark-Khan, C.,Horneck, G. (2003). The SOS-LUX-LACFLUORO-Toxicity-test on the International Space Station (ISS). Adv Space Res, Vol. 31, No. 6, pp. 1513-1524, ISSN: 0273-1177 (Print).

Ramamoorthy, K., Wang, F., Chen, I. C., Norris, J. D., McDonnell, D. P., Leonard, L. S., Gaido, K. W., Bocchinfuso, W. P., Korach, K. S.,Safe, S. (1997). Estrogenic activity of a dieldrin/toxaphene mixture in the mouse uterus, MCF-7 human breast cancer cells, and yeast-based estrogen receptor assays: no apparent synergism. Endocrinology, Vol. 138, No. 4, pp. 1520-1527, ISSN: 0013-7227 (Print).

Raymond-Whish, S., Mayer, L. P., O'Neal, T., Martinez, A., Sellers, M. A., Christian, P. J., Marion, S. L., Begay, C., Propper, C. R., Hoyer, P. B.,Dyer, C. A. (2007). Drinking water with uranium below the US EPA water standard causes estrogen receptordependent responses in female mice. Environmental Health Perspectives, Vol. 115, No. 12, pp. 1711-1716, ISSN: 0091-6765.

Rempel, M. A.,Schlenk, D. (2008). Effects of environmental estrogens and antiandrogens on endocrine function, gene regulation, and health in fish. International Review of Cell and Molecular Biology, Vol 267, Vol. 267, No., pp. 207-252.

Safe, S. H. (2000). Endocrine disruptors and human health-is there a problem? An update. Environ Health Perspect, Vol. 108, No. 6, pp. 487-493, ISSN: 0091-6765 (Print).

Sanceau, J. Y., Larouche, D., Caron, B., Belanger, P., Coquet, A., Belanger, A., Labrie, F.,Gauthier, S. (2007). Synthesis and deuterium labelling of the pure selective estrogen receptor modulator (SERM) acolbifene glucuronides. Journal of Labelled Compounds \& Radiopharmaceuticals, Vol. 50, No. 3-4, pp. 197-206, ISSN: 0362-4803. 
Scanlan, T. S. (2008). Sobetirome: a case history of bench-to-clinic drug discovery and development. Heart Fail Rev, Vol., No., pp., ISSN: 1573-7322 (Electronic).

Schapira, M., Raaka, B. M., Samuels, H. H.,Abagyan, R. (2000). Rational discovery of novel nuclear hormone receptor antagonists. Proc Natl Acad Sci U S A, Vol. 97, No. 3, pp. 1008-1013, ISSN: 0027-8424 (Print).

Schlecht, C., Klammer, H., Frauendorf, H., Wuttke, W.Jarry, H. (2008). Pharmacokinetics and metabolism of benzophenone 2 in the rat. Toxicology, Vol. 245, No. 1-2, pp. 1117, ISSN: 0300-483X (Print).

Seidlova-Wuttke, D., Jarry, H., Christoffel, J., Rimoldi, G.,Wuttke, W. (2005). Effects of bisphenol-A (BPA), dibutylphtalate (DBP), benzophenone-2 (BP2), procymidone (Proc), and linurone (Lin) on fat tissue, a variety of hormones and metabolic parameters: a 3 months comparison with effects of estradiol (E2) in ovariectomized (ovx) rats. Toxicology, Vol. 213, No. 1-2, pp. 13-24, ISSN: 0300-483X (Print).

Seidlova-Wuttke, D., Jarry, H.,Wuttke, W. (2004). Pure estrogenic effect of benzophenone-2 (BP2) but not of bisphenol A (BPA) and dibutylphtalate (DBP) in uterus, vagina and bone. Toxicology, Vol. 205, No. 1-2, pp. 103-112, ISSN: 0300-483X (Print).

Shiau, A. K., Barstad, D., Loria, P. M., Cheng, L., Kushner, P. J., Agard, D. A.,Greene, G. L. (1998). The structural basis of estrogen receptor/coactivator recognition and the antagonism of this interaction by tamoxifen. Cell, Vol. 95, No. 7, pp. 927-937, ISSN: 0092-8674 (Print).

Shiau, A. K., Barstad, D., Radek, J. T., Meyers, M. J., Nettles, K. W., Katzenellenbogen, B. S., Katzenellenbogen, J. A., Agard, D. A.,Greene, G. L. (2002). Structural characterization of a subtype-selective ligand reveals a novel mode of estrogen receptor antagonism. Nat Struct Biol, Vol. 9, No. 5, pp. 359-364, ISSN: 1072-8368 (Print).

Skretas, G., Meligova, A. K., Villalonga-Barber, C., Mitsiou, D. J., Alexis, M. N., MichaScrettas, M., Steele, B. R., Screttas, C. G.,Wood, D. W. (2007). Engineered chimeric enzymes as tools for drug discovery: generating reliable bacterial screens for the detection, discovery, and assessment of estrogen receptor modulators. J Am Chem Soc, Vol. 129, No. 27, pp. 8443-8457, ISSN: 0002-7863 (Print).

Skretas, G.,Wood, D. W. (2005a). A bacterial biosensor of endocrine modulators. J Mol Biol, Vol. 349, No. 3, pp. 464-474, ISSN: 0022-2836 (Print).

Skretas, G.,Wood, D. W. (2005b). Rapid detection of subtype-selective nuclear hormone receptor binding with bacterial genetic selection. Appl Environ Microbiol, Vol. 71, No. 12, pp. 8995-8997, ISSN: 0099-2240 (Print).

Skretas, G.,Wood, D. W. (2005c). Regulation of protein activity with small-moleculecontrolled inteins. Protein Sci, Vol. 14, No. 2, pp. 523-532, ISSN: 0961-8368 (Print).

Smeets, J. M., Rankouhi, T. R., Nichols, K. M., Komen, H., Kaminski, N. E., Giesy, J. P.,van den Berg, M. (1999). In vitro vitellogenin production by carp (Cyprinus carpio) hepatocytes as a screening method for determining (anti)estrogenic activity of xenobiotics. Toxicol Appl Pharmacol, Vol. 157, No. 1, pp. 68-76, ISSN: 0041-008X (Print).

Strumylaite, L., Bogusevicius, A., Ryselis, S., Pranys, D., Poskiene, L., Kregzdyte, R., Abdrachmanovas, O.,Asadauskaite, R. (2008). Association between cadmium and breast cancer. Medicina-Lithuania, Vol. 44, No. 6, pp. 415-420, ISSN: 1010-660X.

Tancevski, I., Eller, P., Patsch, J. R.,Ritsch, A. (2009). The resurgence of thyromimetics as lipid-modifying agents. Current Opinion in Investigational Drugs, Vol. 10, No. 9, pp. 912-918. 
Tani, C., Inoue, K., Tani, Y., Harun-ur-Rashid, M., Azuma, N., Ueda, S., Yoshida, K.,Maeda, I. (2009). Sensitive fluorescent microplate bioassay using recombinant Escherichia coli with multiple promoter-reporter units in tandem for detection of arsenic. $J$ Biosci Bioeng, Vol. 108, No. 5, pp. 414-420, ISSN: 1347-4421 (Electronic).

Tokumoto, T., Tokumoto, M.,Thomas, P. (2007). Interactions of diethylstilbestrol (DES) and DES analogs with membrane progestin receptor-alpha and the correlation with their nongenomic progestin activities. Endocrinology, Vol. 148, No. 7, pp. 3459-3467, ISSN: 0013-7227.

Vahter, M., Akesson, A., Liden, C., Ceccatelli, S.,Berglund, M. (2007). Gender differences in the disposition and toxicity of metals. Environmental Research, Vol. 104, No. 1, pp. 85-95, ISSN: 0013-9351.

Vandenberg, L. N., Hauser, R., Marcus, M., Olea, N.,Welshons, W. V. (2007). Human exposure to bisphenol A (BPA). Reproductive Toxicology, Vol. 24, No. 2, pp. 139-177, ISSN: 0890-6238.

Vandenberg, L. N., Maffini, M. V., Sonnenschein, C., Rubin, B. S.,Soto, A. M. (2009). Bisphenol-A and the great divide: a review of controversies in the field of endocrine disruption. Endocr Rev, Vol. 30, No. 1, pp. 75-95, ISSN: 1945-7189 (Electronic).

Wagner, R. L., Huber, B. R., Shiau, A. K., Kelly, A., Cunha Lima, S. T., Scanlan, T. S., Apriletti, J. W., Baxter, J. D., West, B. L.,Fletterick, R. J. (2001). Hormone selectivity in thyroid hormone receptors. Mol Endocrinol, Vol. 15, No. 3, pp. 398-410, ISSN: 0888-8809 (Print).

Werlen, C., Jaspers, M. C.,van der Meer, J. R. (2004). Measurement of biologically available naphthalene in gas and aqueous phases by use of a Pseudomonas putida biosensor. Appl Environ Microbiol, Vol. 70, No. 1, pp. 43-51, ISSN: 0099-2240 (Print).

Wilkinson, P. M., Ribiero, G. G., Adam, H. K., Kemp, J. V.,Patterson, J. S. (1982). Tamoxifen (Nolvadex) therapy-radionale for loading dose followed by maintenance dose for patients with metastatic breast cancer. Cancer Chemother Pharmacol, Vol. 10, No. 1, pp. 33-35, ISSN: 0344-5704 (Print).

Wood, D. W., Wu, W., Belfort, G., Derbyshire, V.,Belfort, M. (1999). A genetic system yields self-cleaving inteins for bioseparations. Nat Biotechnol, Vol. 17, No. 9, pp. 889-892, ISSN: 1087-0156 (Print).

Zauhar, R. J. (1995). SMART: a solvent-accessible triangulated surface generator for molecular graphics and boundary element applications. J Comput Aided Mol Des, Vol. 9, No. 2, pp. 149-159, ISSN: 0920-654X (Print).

Zauhar, R. J., Moyna, G., Tian, L., Li, Z.,Welsh, W. J. (2003). Shape signatures: a new approach to computer-aided ligand- and receptor-based drug design. J Med Chem, Vol. 46, No. 26, pp. 5674-5690, ISSN: 0022-2623 (Print).

Zhang, J. H., Chung, T. D.,Oldenburg, K. R. (1999). A Simple Statistical Parameter for Use in Evaluation and Validation of High Throughput Screening Assays. J Biomol Screen, Vol. 4, No. 2, pp. 67-73, ISSN: 1552-454X (Electronic). 


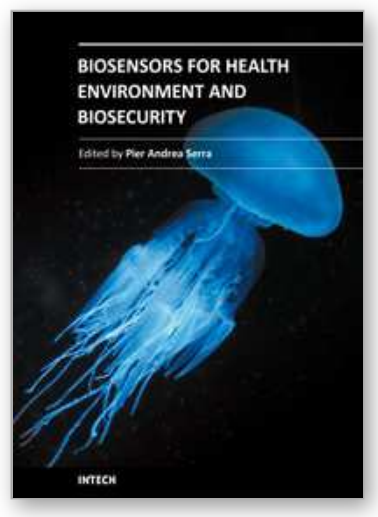

\author{
Biosensors for Health, Environment and Biosecurity \\ Edited by Prof. Pier Andrea Serra
}

ISBN 978-953-307-443-6

Hard cover, 540 pages

Publisher InTech

Published online 19, July, 2011

Published in print edition July, 2011

\begin{abstract}
A biosensor is a detecting device that combines a transducer with a biologically sensitive and selective component. Biosensors can measure compounds present in the environment, chemical processes, food and human body at low cost if compared with traditional analytical techniques. This book covers a wide range of aspects and issues related to biosensor technology, bringing together researchers from 16 different countries. The book consists of 24 chapters written by 76 authors and divided in three sections: Biosensors Technology and Materials, Biosensors for Health and Biosensors for Environment and Biosecurity.
\end{abstract}

\title{
How to reference
}

In order to correctly reference this scholarly work, feel free to copy and paste the following:

Izabela Gierach and David Wood (2011). Engineered Nuclear Hormone Receptor-Biosensors for Environmental Monitoring and Early Drug Discovery, Biosensors for Health, Environment and Biosecurity, Prof. Pier Andrea Serra (Ed.), ISBN: 978-953-307-443-6, InTech, Available from:

http://www.intechopen.com/books/biosensors-for-health-environment-and-biosecurity/engineered-nuclearhormone-receptor-biosensors-for-environmental-monitoring-and-early-drug-discovery

\section{INTECH}

open science | open minds

\section{InTech Europe}

University Campus STeP Ri

Slavka Krautzeka 83/A

51000 Rijeka, Croatia

Phone: +385 (51) 770447

Fax: +385 (51) 686166

www.intechopen.com

\section{InTech China}

Unit 405, Office Block, Hotel Equatorial Shanghai

No.65, Yan An Road (West), Shanghai, 200040, China

中国上海市延安西路65号上海国际贵都大饭店办公楼405单元

Phone: +86-21-62489820

Fax: $+86-21-62489821$ 
(C) 2011 The Author(s). Licensee IntechOpen. This chapter is distributed under the terms of the Creative Commons Attribution-NonCommercialShareAlike-3.0 License, which permits use, distribution and reproduction for non-commercial purposes, provided the original is properly cited and derivative works building on this content are distributed under the same license. 